\title{
Advance and Retreat of Cordilleran Ice Sheets in Washington,
} U.S.A.

\author{
Avancée et recul des inlandsis de la Cordillère dans l'État de \\ Washington (É.-U.) \\ Vorstoß und Rückzug der Kordilleren-Eisdecke in Washington \\ State. U.S.A.
}

\author{
Don J. Easterbrook
}

Volume 46, numéro 1, 1992

URI : https://id.erudit.org/iderudit/032888ar

DOI : https://doi.org/10.7202/032888ar

\section{Aller au sommaire du numéro}

\section{Éditeur(s)}

Les Presses de l'Université de Montréal

\section{ISSN}

0705-7199 (imprimé)

1492-143X (numérique)

\section{Découvrir la revue}

\section{Citer cet article}

Easterbrook, D. J. (1992). Advance and Retreat of Cordilleran Ice Sheets in Washington, U.S.A. Géographie physique et Quaternaire, 46(1), 51-68. https://doi.org/10.7202/032888ar

\section{Résumé de l'article}

Dans la Cordillère, les glaciations se sont produites selon des modes caractéristiques d'avancée et de recul : 1) dépôts fluvioglaciaires d'avancée; 2) poli glaciaire; 3) till; 4) dépôts fluvio-glaciaires de retrait au sud de Seattle, dans le sud des basses-terres de Puget, dépôts glacio-marins dans les basses-terres du nord, et eskers, terrasses fluvioglaciaires et petites moraines sur le plateau de Columbia. La datation au radiocarbone indique que les lobes de Puget et de Juan de Fuca ont avancé et reculé synchroniquement. Parmi les preuves qui nous contraignent à rejeter l'hypothèse selon laquelle un front en fusion, qui vêlait, serait à l'origine des dépôts glacio-marins, citons : 1) les nombreuses datations au radiocarbone qui révèlent la mise en place simultanée de dépôts glacio-marins sur tout le territoire; 2) les dépôts issus de la fusion de la glace stagnante, intimement associés aux dépôts glacio-marins; 3) les preuves irréfutables d'une origine autre que marine des sables de Deming qui révèlent que la Cordillère était libre de glace immédiatement avant la mise en place des dépôts glacio-marins. Dans le nord des basses-terres de Puget le déroulement des événements comprend les étapes suivantes : 1) au cours du maximum de Vashon, charge glaciaire sous $1800 \mathrm{~m}$ de glace; 2) 12-13 ka BP, amincissement rapide du glacier et dérive de la glace contribuant à la mise en place des dépôts glacio-marins de Kulshan; 3) vers 11500 ans BP, emersion et dépôt des sables de Deming d'origine fluviale; 4) nouvelle submersion et mise en place des dépôts glacio-marins de Bellingham jusqu'à une hauteur d'environ $200 \mathrm{~m}$, bien supérieure à l'élévation eustatique du niveau de la mer; 5) vers 10 500-11 500 ans BP, emersion et mise en place des dépôts fluvio-glaciaires de Sumas sur les dépôts glacio-marins de Bellingham; 6) à l'Holocène, élévation eustatique du niveau de la mer au même rythme que le relèvement isostatique. 


\section{ADVANCE AND RETREAT OF CORDILLERAN ICE SHEETS IN WASHINGTON, U.S.A.*}

Don J. EASTERBROOK, Department of Geology, Western Washington University, Bellingham, Washington 98225, U.S.A.

ABSTRACT Cordilleran Ice Sheet glaciations show characteristic patterns of advance and retreat, consisting of (1) advance outwash, (2) glacial scouring, (3) deposition of till, (4) deposition of recessional outwash south of Seattle in the southern Puget Lowland, glaciomarine drift in the northern lowland, and eskers, kames, and small moraines on the Columbia Plateau. Radiocarbon dates show that the Puget and Juan de Fuca lobes advanced and retreated synchronously. The Puget lobe backwasted to Seattle by 13.4-14 ka yrs BP, where the thinning ice floated in seawater northward to Canada by 13 ka yrs BP depositing glaciomarine drift contemporaneously over $18,000 \mathrm{~km}^{2}$. Compelling evidence against the backwasting, calving, terminus model for the origin of the glaciomarine drift includes: 1) abundant ${ }^{14} \mathrm{C}$ dates demonstrate simultaneous deposition of glaciomarine drift over the entire area; 2) stagnant-ice deposits closely related to glaciomarine drift are not consistent with an actively-calving, backwasting terminus; 3) irrefutable evidence for the nonmarine origin of Deming sand shows that Cordilleran ice was absent immediately prior to deposition of the overlying glaciomarine drift. The pattern of events in the northern Puget Lowland includes: 1) glacial loading under $1800 \mathrm{~m}$ of ice during the Vashon maximum; 2) rapid glacial thinning and floating of the ice deposited Kulshan glaciomarine drift 12-13 ka yrs BP; 3) emergence and deposition of fluvial Deming sand $\sim 11.5$ ka yrs BP; 4 ) resubmergence and deposition of Bellingham glaciomarine drift up to $\sim 200 \mathrm{~m}$, well beyond global eustatic sea level rise; 5) emergence $\sim 10.5-11.5 \mathrm{ka}$ yrs BP and deposition of Sumas outwash on Bellingham glaciomarine drift; 6) Holocene eustatic sea level rise kept pace with isostatic rebound, thus, post-Sumas marine terraces are absent.
RÉSUMÉ Avancée et recul des inlandsis de la Cordillère dans l'État de Washington (É.-U). Dans la Cordillère, les glaciations se sont produites selon des modes caractéristiques d'avancée et de recul: 1) dépôts fluvioglaciaires d'avancée; 2) poli glaciaire; 3) till; 4) dépôts fluvio-glaciaires de retrait au sud de Seattle, dans le sud des basses-terres de Puget, dépôts glacio-marins dans les bassesterres du nord, et eskers, terrasses fluvioglaciaires et petites moraines sur le plateau de Columbia. La datation au radiocarbone indique que les lobes de Puget et de Juan de Fuca ont avancé et reculé synchroniquement. Parmi les preuves qui nous contraignent à rejeter l'hypothèse selon laquelle un front en fusion, qui vélait, serait à l'origine des dépôts glacio-marins, citons: 1) les nombreuses datations au radiocarbone qui révèlent la mise en place simultanée de dépôts glacio-marins sur tout le territoire; 2) les dépôts issus de la fusion de la glace stagnante, intimement associés aux dépôts glacio-marins; 3 ) les preuves irréfutables d'une origine autre que marine des sables de Deming qui révèlent que la Cordillère était libre de glace immédiatement avant la mise en place des dépôts glaciomarins. Dans le nord des basses-terres de Puget le déroulement des événements comprend les étapes suivantes: 1) au cours du maximum de Vashon, charge glaciaire sous $1800 \mathrm{~m}$ de glace; 2) $12-13 \mathrm{ka} \mathrm{BP}$, amincissement rapide du glacier et dérive de la glace contribuant à la mise en place des dépôts glacio-marins de Kulshan; 3) vers 11500 ans $\mathrm{BP}$, émersion et dépôt des sables de Deming d'origine fluviale; 4) nouvelle submersion et mise en place des dépôts glacio-marins de Bellingham jusqu'à une hauteur d'environ $200 \mathrm{~m}$, bien supérieure à l'élévation eustatique du niveau de la mer; 5) vers 10500 11500 ans BP, émersion et mise en place des dépôts fluvio-glaciaires de Sumas sur les dépôts glacio-marins de Bellingham; 6) à I'Holocène, élévation eustatique du niveau de la mer au même rythme que le relèvement isostatique.
ZUSAMMENFASSUNG Vorstoß und Rückzug der Kordilleren-Eisdecke in Washington State. U.S.A. Die Vereisung der Kordilleren-Eisdecke zeigt charakteristische Vorstoß- und Rückzugsmuster, bestehend aus (1) glazialem Schwemmvorstoß, (2) glazialem Scheuern, (3) Ablagerung der Grundmoräne, (4) Ablagerung von Rückzugsschwemm-Material südlich von Seattle im südlichen Puget-Lowland, glaziomarines Material im nördlichen Tiefland und Esker, Kames und kleine Moränen auf dem Columbia-Plateau. Radiokarbondaten zeigen, daß die Puget - und Juan de Fuca-Loben gleichzeitig vorstießen und sich zurückzogen. Gegen das rückläufige, kalbende TerminusModell für den Ursprung des glaziomarinen Materials sprechen die folgenden Tatsachen in zwingender Weise: 1) zahlreiche ${ }^{14} \mathrm{C}$-Daten beweisen die gleichzeitige Ablagerung von glaziomarinem Material über das gesamte Gebiet; 2) Ablagerungen von stagnierendem Eis, die in enger Verbindung zu glaziomarinem Material stehen, stimmen nicht mit einem aktiv kalbenden rückläufigen Terminus überein; 3) unwiderlegbares Beweismaterial für den nichtmarinen Ursprung des Sands von Deming zeigt, daß es kein Kordilleren-Eis gab unmittelbar vor der Ablagerung darüberliegenden glaziomarinen Materials. Die Abfolge der Ereignisse im nördlichen Puget Lowland beinhaltet: 1) glaziale Fracht unter $1800 \mathrm{~m}$ Eis während des Vashon Maximums; 2) schnelles glaziales Ausdünnen und treibendes Eis lagerte 12-13 ka Jahre v.u.Z. das glaziomarine Material von Kulshan ab; 3) Auftauchen und Ablagerung von Deming-Flußsand - $11.5 \mathrm{ka}$ Jahre v.u.Z.; 4) Wiederuntertauchen und Ablagerung von glaziomarinem Belligham-Material bis zu $200 \mathrm{~m}$, weit über die globale eustatische Meeresanhebung hinaus; 5) Auftauchen 10.5-11.5 ka Jahre v.u.Z. und Ablagerung von SumasSchwemm-Material auf dem glaziomarinen Bellingham-Material; 6) die eustatische Anhebung des Meeresspiegels im Holozän hielt Schritt mit dem isostatischen Rückprall.

\footnotetext{
* The present article is a follow up to the special issue dedicated to the Cordilleran Ice Sheet (Vol. 45, No. 3) / Cet article constitue la suite du numéro spécial consacré à l'Inlandsis de la Cordillère (vol. $45, n^{\circ} 3$ ). Manuscrit reçu le 11 mars 1991; manuscrit révisé accepté le 22 octobre 1991
} 


\section{INTRODUCTION}

The southern margin of the Pleistocene Cordilleran Ice Sheet in Washington was highly lobate, largely as a result of topographic restrictions. The western part of the ice sheet split into two lobes, the Puget and Juan de Fuca lobes, constrained by the Cascade Range and the Olympic Mountains. The eastern part split into a large lobe, the Okanogan, and four smaller lobes occupying north-south trending valleys (Richmond, 1986; Waitt and Thorson, 1983), as well as a number of other lobes in Idaho and Montana (Fig. 1).

Evidence from multiple dating methods accumulated in the past decade shows that the Cordilleran Ice Sheet advanced into and retreated from western Washington at least six times during the Pleistocene (Easterbrook, 1986; Easterbrook et al., 1988; Blunt et al., 1987; Westgate et al., 1987), and although evidence from the eastern lobes is not as definitive or as well dated, these lobes presumably followed a similar pattern. Because deposits of the Juan de Fuca and Puget lobes are well exposed along many kilometers of sea cliffs and well dated by radiocarbon, fission-track, amino acid, paleomagnetic, and tephra correlation methods, attention is focused here on their advance and retreat characteristics, and, where possible, correlated with events east of the Cascades.

Comparison of the characteristics of the advances and retreats of the six known glaciations in the Puget Lowland reveals a strikingly similar pattern, especially for the last three glaciations. The chronology of the advance and retreat of the Late Wisconsinan Fraser Glaciation in the Puget Lowland has been worked out over the past several decades (Armstrong et al., 1965; Crandell et al., 1958; Blunt et al., 1987; Easterbrook, 1963, 1969, 1986; Easterbrook et al., 1981, 1988; Mullineaux et al., 1965; Westgate et al., 1987), and now comprises one of the best-dated, long-record, Pleistocene sequences in the world. However, papers published during the same time period on interpretations of specific depositional environments of some of the sediments have not always been in accord with one another. Among the objectives of this paper are (1) examination of the physical evidence for glaciological events during advance and retreat of the Cordilleran Ice Sheet, (2) reconciliation of the evidence with interpretations of depositional conditions, and (3) use of the well-established chronology to accurately correlate sediments from place to place to aid in evaluation of glaciological conditions during advance and retreat of the ice sheet.

Evidence of the three oldest recognized glaciations of the Cordilleran Ice Sheet, the Orting, Stuck, and Salmon Springs, is known only for the Puget lobe where erosion has cut through younger sediments. Glacial drifts of these three glaciations are exposed only in the southern Puget Lowland where they lie beneath the one million year old Lake Tapps Tephra (Easterbrook, 1986; Easterbrook et al., 1981, 1988; Westgate et al., 1987). Because they are not exposed above sea level in the northern and central Puget Lowland, evidence of the nature of their advance and retreat is sparse and they are thus not discussed here.

The three youngest glaciations of the Puget and Juan de Fuca lobes, the Double Bluff, Possession, and Fraser, are best exposed in the northern and central Puget Lowland where they extend to and somewhat below sea level, making them suitable for studying the characteristics of advance and retreat of the Cordilleran Ice Sheet. Equivalent advances of the lobes east of the Cascade Range are unknown, largely because deposits of the Fraser Glaciation cover any older drift units. Glacial deposits of the Fraser Glaciation are very well dated by radiocarbon in western Washington, but even limiting dates for advances and retreats of the lobes in eastern Washington are extremely rare.

Thermoluminescence and amino acid dates on Double Bluff Drift, Whidbey interglacial sediments, and Possession Drift show that a gap of some 800,000 years exists in the stratigraphic record in the Puget Lowland, between about 200,000 years and one million years. Still more glaciations may have

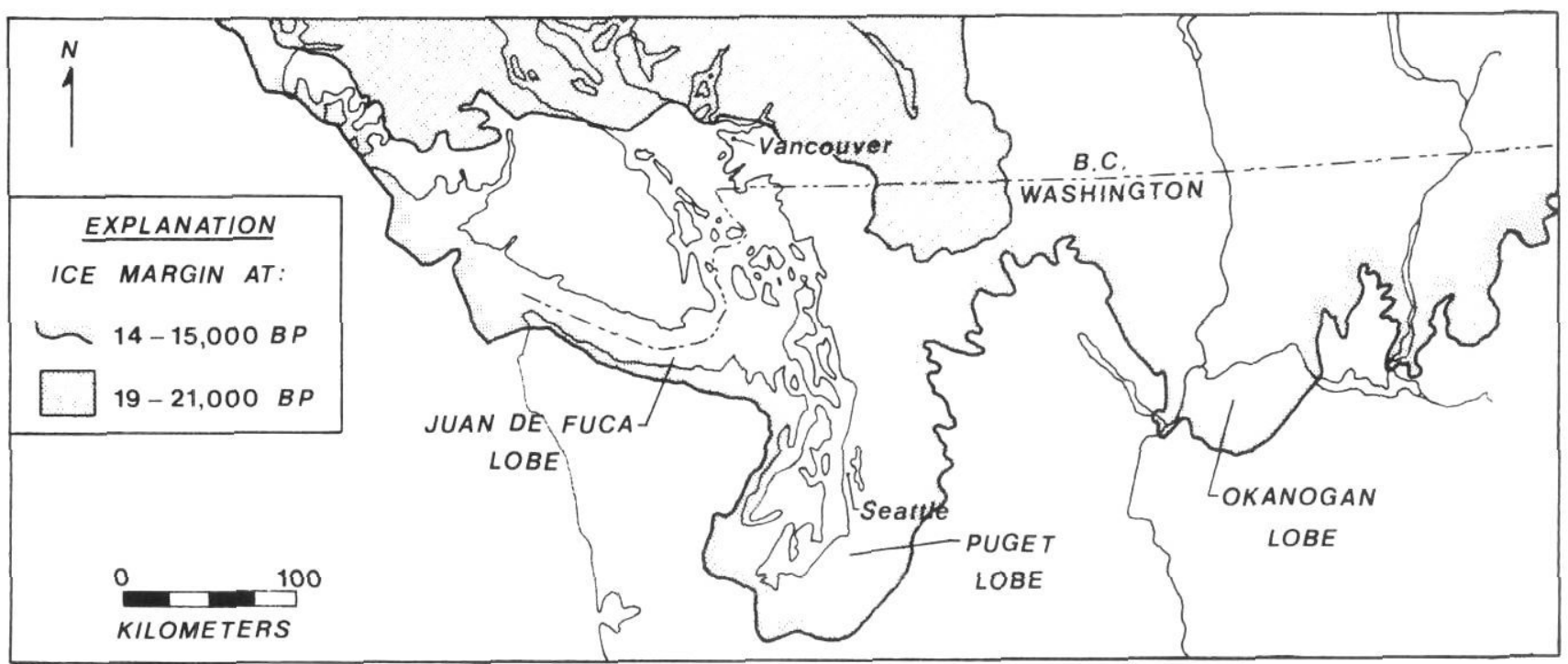

FIGURE 1. Map showing lobes of the Cordilleran Ice Sheet (modified after Clague, 1980).

Carte représentant des lobes de l'Inlandsis de la Cordillère (modifiée à partir de Clague, 1980). 
occurred during this time, but sediments in this age range are not known above sea level and are thus not available for study. Several hundred meters of unconsolidated sediments older than about 200,000 years show up in seismic data below sea level in the central Puget Lowland, but deep well records and sample data are extremely meager.

\section{NATURE OF ADVANCES OF THE CORDILLERAN ICE SHEET}

The best evidence for the specific nature of each advance and retreat of the Cordilleran lce Sheet is found in the many miles of sea cliff exposures of the Puget Lowland. Thus, most of the discussion here will focus on the Puget and Juan de Fuca lobes. The Puget lobe formed as Cordilleran ice extended southward into the Puget Lowland between the Cascade Range and the Olympic Mts. and the Juan de Fuca lobe formed as the ice flowed westward toward the Pacific Ocean between Vancouver Island and the Olympic Mountains (Fig. 1).

Each of the three glacial units considered here, Double Bluff Drift, Possession Drift, and Fraser Drift, typically consists of a package of sediments showing a characteristic pattern of advance of the ice sheet. The advance phase of each glaciation typically consists of (1) deposition of outwash sand and gravel ahead of the advancing ice, (2) scouring by overriding of the glacier, and (3) deposition of till and related drift.

\section{DOUBLE BLUFF GLACIATION}

Double Bluff Drift is named for glaciofluvial gravel, sand and silt, till, and glaciomarine drift at Double Bluff on Whidbey island (Fig. 2) (Easterbrook et al., 1967; Easterbrook, 1968, 1969, 1986; Blunt et al., 1987). Over much of the Puget Lowland, it is buried beneath younger sediments, but is exposed in the base of sea cliffs near sea level in the central Puget Lowland where it lies stratigraphically beneath the Whidbey Formation of the last major interglaciation. Underlying sediments are not exposed above sea level, although seismic data suggests that several hundred meters of sediment may underlie Double Bluff Drift between Seattle and the type locality.

Amino acid measurements of shells in Double Bluff glaciomarine drift at the type locality and from glaciomarine drift in the southwestern Puget Lowland suggest an age of about 150-200 ka. (Easterbrook and Rutter, 1981, 1982; Blunt et al., 1987). Thermoluminescence dates of glaciomarine drift at the type locality and from underlying clay to the north suggest a similar age (Berger, personal communication).

At its type locality, Double Bluff Drift consists of 5-10 m of compact gray till with irregular lenses of sand and gravel underlain by up to seven $\mathrm{m}$ of cut-and-fill sand and pebble-cobble gravel in channels cut into $\sim 10 \mathrm{~m}$ of crossbedded to massive, sand (Fig. 3). A wedge-shaped lens of fossiliferous glaciomarine drift few meters thick overlies the till (Easterbrook et al., 1967). Pebbles of distinctive granite and garnet-schist in the till and underlying gravel establish a British Columbia source for both. Thus, the gravel is interpreted to be outwash deposited in front of the advancing glacier. Exposures of Double Bluff Drift elsewhere are quite rare, so the base of the drift is seldom exposed. In a few places, it lies on outwash sand and gravel or silt of probable glaciolacustrine origin.
Thus, although exposures are not abundant, the Double Bluff Glaciation seems to have begun with the spreading of outwash in front of the ice as it advanced into the Puget Lowland, followed by overriding of outwash by the glacier and deposition of till. The paucity of exposures does not allow an accurate assessment of the amount of glacial erosion that may have occurred prior to deposition of the till.

\section{POSSESSION GLACIATION}

Possession Drift consists of compact, sandy till, sand and gravel, and stony clay glaciomarine drift (Easterbrook et al., 1967). At its type locality at Possession Point (Fig. 2), it consists of a single till sheet up to 25 meters thick that thins and wedges out completely within about one kilometer to the west. Elsewhere in the central and southwestern Puget Lowland, it occurs as discontinuous lenses of till (Fig. 4), outwash sand and gravel, and glaciomarine drift (Easterbrook, 1968, 1969, 1976a, 1986, 1987; Deeter, 1979; Blunt et al., 1987).

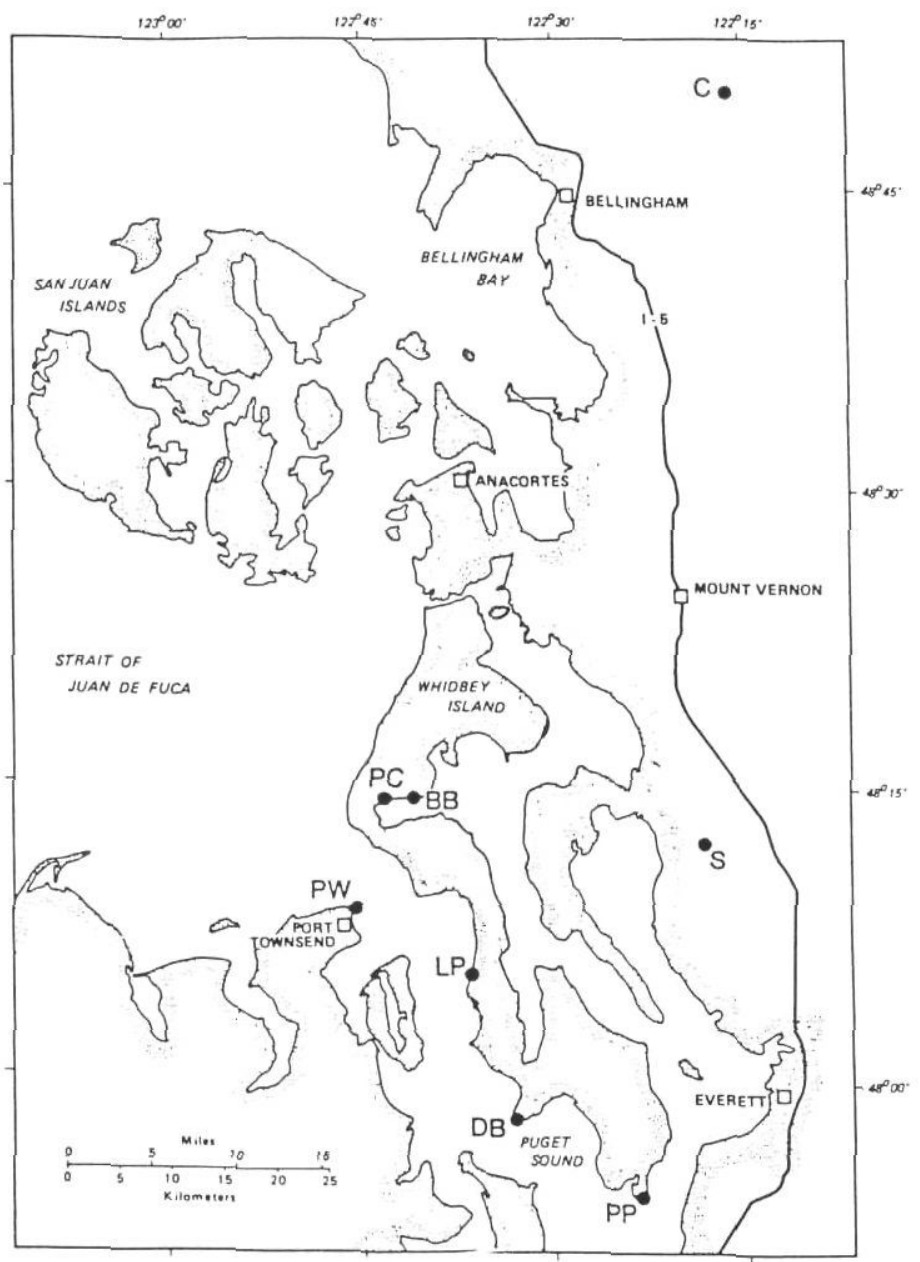

FIGURE 2. Map of the central and northern Puget Lowland showing locations of places discussed in the text. $D B=$ Double Bluff; $\mathrm{PP}=$ Possession Point; $\mathrm{LP}=$ Lagoon Point; $\mathrm{PW}=$ Point Wilson; $\mathrm{PC}=$ Penn Cove; $\mathrm{BB}=$ Blowers Bluff; $\mathrm{S}=$ Stillaguamish; $\mathrm{C}=$ Cedarville.

Carte du centre et du nord des basses terres de Puget, représentant les lieux mentionnés dans le texte. $D B=$ Double Bluff; $P P=$ Possession Point; $L P=$ Lagoon Point; $P W=$ Point Wilson; $P C=P e n n$ Cove; $B B=$ Blowers Bluff; $S=$ Stillaguamish; $C=$ Cedarville. 


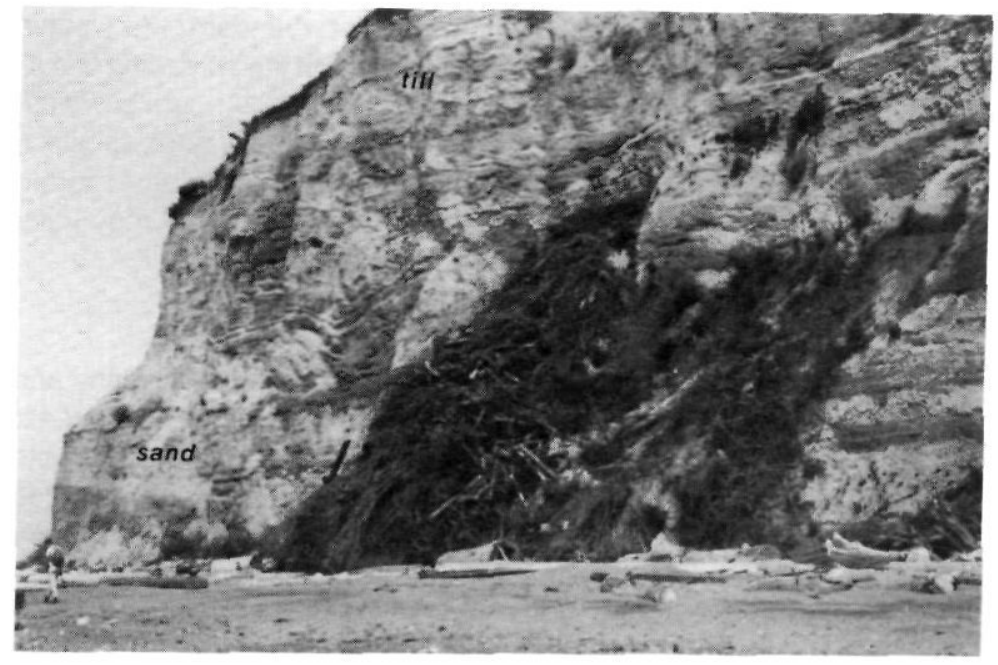

FIGURE 3. Stratigraphic section at the type locality of the Double Bluff Drift on Whidbey Island. Double Bluff till overlies advance sand and gravel. Several hundred meters to the right of the photo, Double Bluff glaciomarine drift overlies the till.

Coupe stratigraphique au site de référence des dépôts de Double Bluff, dans Whidbey Island. Le till de Double Bluff recouvre des sables et des graviers d'avancée glaciaire. À droite, à plusieurs centaines de mètres, les dépôts glacio-marins de Double Bluff recouvrent le till.

FIGURE 4. Thick Possession till, near Lagoon Point, Whidbey Island.

Grande épaisseur du till de Possession, près de Lagoon Point, dans l'île Whidbey.

At numerous locations in the Puget Lowland, an unconformity occurs at the stratigraphic position of Possession Drift, and younger sediments rest directly on the underlying Whidbey Formation of the last interglaciation. In other places, outwash sand and gravel occupy this stratigraphic position, but whether or not it represents Possession advance outwash is difficult to determine because of the discontinuous nature of deposits.

Although the evidence is not as clear as for the Double Bluff Drift, Possession till overlying outwash at a number of places suggests that the Possession glacier advanced over its own outwash. The base of Possession till at the type locality is about $40 \mathrm{~m}$ above sea level but elsewhere varies from near sea level to $45 \mathrm{~m}$ above. Clearly, Possession till was deposited on a surface of at least moderate relief, but continuous exposures are not long enough to demonstrate whether the relief is glacial or nonglacial in origin.

\section{FRASER GLACIATION}

The last major glaciation of Washington, the Fraser Glaciation, consists of multiple stades, (1) the Evans Creek, an early alpine phase; (2) the Vashon stade, the maximum advance of the Cordilleran Ice Sheet; (3) the Everson interstade, an interval of glaciomarine deposition during deglaciation of the lowland; and (4) the Sumas stade, a short readvance of the ice margin before complete deglaciation (Armstrong et al., 1965). The Fraser was preceded by a nonglacial interval, the Olympia, represented by nonglacial floodplain and lacustrine silt, clay, and peat. Radiocarbon dates from Olympia sediments at their type locality in Seattle range from 18 to $22 \mathrm{ka}$ (Mullineaux et al., 1965) and ages in the central Puget Lowland extend from 22 to 28 ka (Hansen and Easterbrook, 1974;

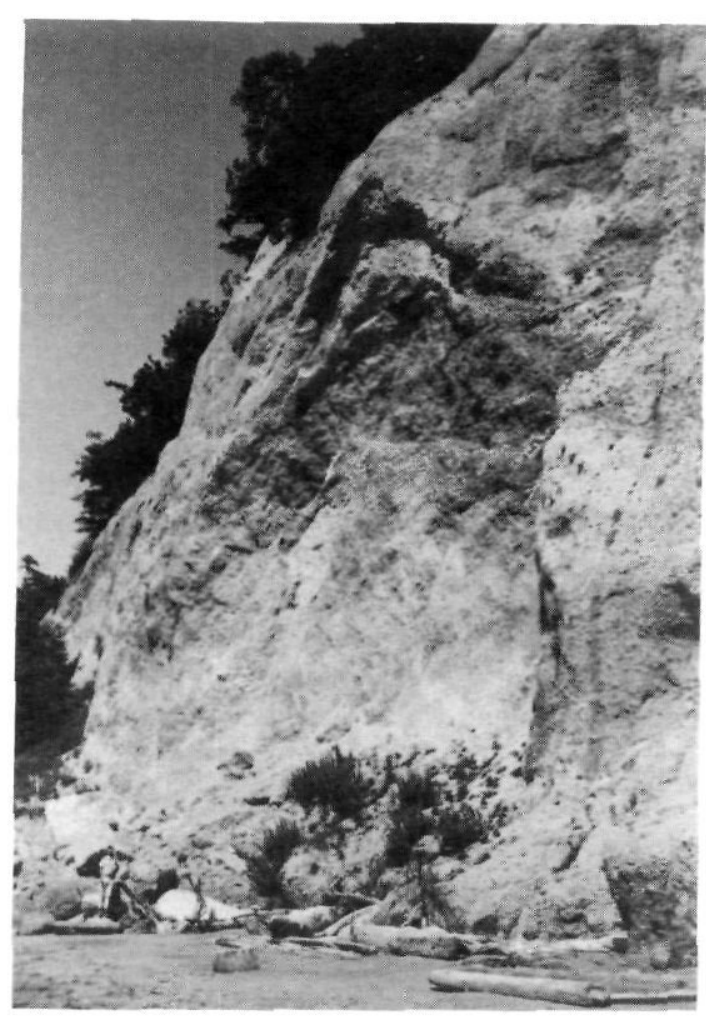

Easterbrook, 1976a, 1986). Dates as young as $15 \mathrm{ka}$ have been obtained from sediments directly beneath Vashon till in the Seattle area and in Kitsap County (Mullineaux et al., 1965; Deeter, 1979).

Near the end of the Olympia interval, piedmont ice advanced into the Fraser Lowland of British Columbia just north of the international boundary and deposited Coquitlam Drift (Hicock, 1976, 1980; Armstrong, 1977; Clague et al., 1980; Hicock and Armstrong, 1981; Clague and Luternauer, 1982, 1983; Armstrong et al., 1985), but the ice either did not reach into Washington or its deposits have been buried by younger sediments. Radiocarbon dates from wood in Coquitlam Drift range from 21,3 to 25,8 ka and mammoth tusks from Coquitiam outwash have been ${ }^{14} \mathrm{C}$-dated at 21,4 to $21,6 \mathrm{ka}$ (Figs. 1 and 5, Table I) (Clague, 1980; Armstrong et al., 1985; Hicock et al., 1982). ${ }^{14} \mathrm{C}$ dates ranging from 17,8 to 18,7 ka were obtained from overlying organic material (Table I). The Coquitlam Drift is correlated with the Evans Creek Stade of the Fraser Glaciation (Armstrong and Clague, 1977). During this time, deposition of Olympia nonglacial sediments continued in the Puget Lowland to the south.

Vashon Drift consists of (1) the Esperance Sand Member (Fig. 6) and Quadra Sand, deposited by meltwater streams from the advancing Cordilleran Ice Sheet (Fig. 7) (Newcomb, 1952; Mullineaux et al., 1965; Clague, 1976, 1977), (2) Vashon till (Willis, 1898; Bretz, 1913) which overlies the Esperance, and (3) recessional outwash sand, gravel, and ice-contact deposits. During the early Vashon advance, the Cordilleran Ice Sheet extended southward into the Fraser Lowland of British Columbia, depositing till and outwash on glaciolacustrine sed- 
iments radiocarbon dated at 18,700 \pm 170 (GSC-2344) and $17,800 \pm 150$ (GSC-2297) years (Clague, 1980; Armstrong et al., 1985; Hicock et al., 1982; Hicock and Armstrong, 1985). Other radiocarbon dates that limit the age of the Vashon advance include peat in the Esperance Sand Member at the east end of the Strait of Juan de Fuca, radiocarbon dated at $18,000 \pm 400$ (I-2282) years (Easterbrook, 1969) and organic material from floodplain sediments in the south-central Puget Lowland, dated at 16,510 \pm 320 (UW-445), 15,450 \pm 450

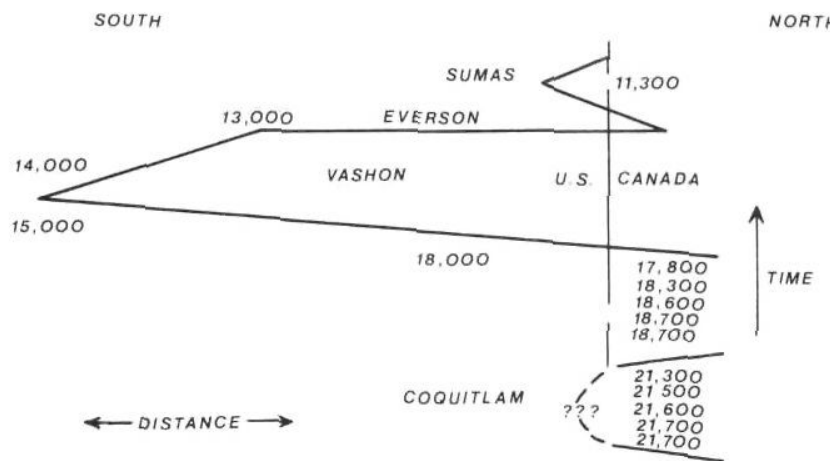

FIGURE 5. Radiocarbon chronology for the early Fraser Glaciation. Chronologie de la Glaciation de Fraser, déterminée au radiocarbone.

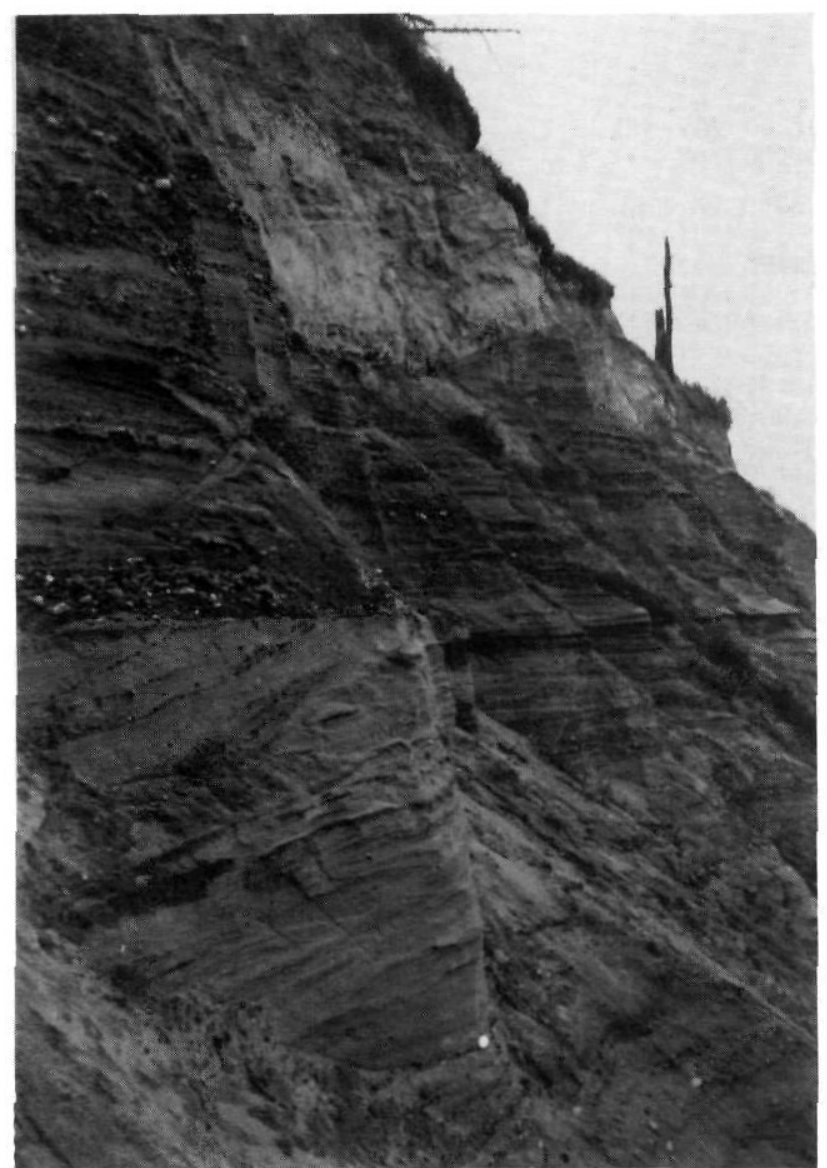

FIGURE 6. Crossbedded Vashon advance outwash (Esperance sand) beneath Vashon till, southern Whidbey Island.

Matériel d'épandage fluvio-glaciaire entrecroisé de Vashon (sables d'Espérance) sous le till de Vashon, dans le sud de Whidbey Island.
(UW-448) and 15,350 \pm 210 (I-10374) years (Fig. 8) (Deeter, 1979). Organic matter beneath Vashon Drift in the Seattle area, radiocarbon dated at 15,000 $\pm 400(\mathrm{~W}-1227), 15,100 \pm 300$ $(\mathrm{W}-1305)$, and 16,070 $\pm 600(\mathrm{~W}-2125)$ years (Mullineaux et al., 1965; Yount et al., 1980), indicates that Cordilleran ice did not reach there until sometime not long after 15,000 years (Mullineaux et al., 1965; Yount et al., 1980).

Waitt and Thorson (1983) proposed that the westwardflowing Juan de Fuca lobe (Bretz, 1920) may have been out of phase with the southward-flowing Puget lobe and may have reached the western end of the strait by about 17,000 years,

\section{TABLE I}

Radiocarbon ages from Coquitlam Drift (dates from Clague, 1980 and Armstrong et al., 1985)

${ }^{14} \mathrm{C}$ dates from overlying organic material

$$
\begin{array}{ll}
18,700 \pm 170(\text { GSC }-2344) & 18,600 \pm 190(\text { GSC-2194) } \\
18,300 \pm 170 \text { (GSC-2322) } & 18,000 \pm 150 \text { (GSC-2371) }
\end{array}
$$$$
17,800 \pm 150 \text { (GSC-2297) }
$$

${ }^{14} \mathrm{C}$ dates from wood in Coquitlam Drift

$$
\begin{array}{ll}
25,800 \pm 310(\text { GSC }-2273) & 21,700 \pm 240(\text { GSC }-2235) \\
21,700 \pm 130(\text { GSC }-2416) & 21,600 \pm 200(\text { GSC }-2203) \\
21,500 \pm 240(\text { GSC }-2536) & 21,300 \pm 250(\text { GSC }-3305)
\end{array}
$$

${ }^{14} \mathrm{C}$ dates from mammoth tusks in Coquitlam outwash

$$
21,400 \pm 240 \text { (SFU-65) } \quad 21,600 \pm 240 \text { (SFU-66) }
$$

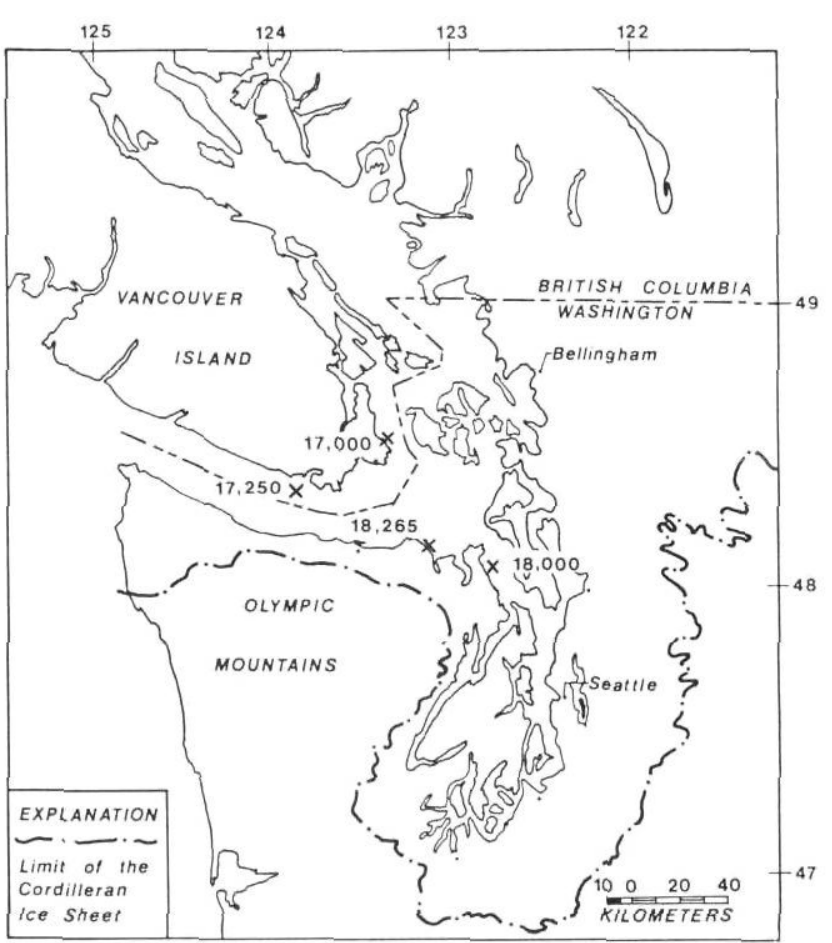

FIGURE 7. Limiting radiocarbon dates for advance of Vashon ice into the Puget Lowland and Strait of Juan de Fuca.

Dates limites, déterminées au radiocarbone, de l'avancée du glacier Vashon dans les basses terres de Puget et dans le détroit de Juan de Fuca. 
several thousand years earlier than the Puget lobe reached its southern terminus. However, ${ }^{14} \mathrm{C}$ dates of $17,000 \pm 240$ (GSC-2829) years from southeastern Vancouver Island (Keddie, 1979); 17,250 \pm 1000 from the central Strait of Juan de Fuca (Anderson, 1968); 17,350 \pm 1260 (B-1062), $18,265 \pm 345$ (B-1063), and 18,000 \pm 400 years (1-2282) from the southeastern Strait of Juan de Fuca (Easterbrook, 1969) indicate that the lobe had not yet entered the eastern strait by 17 ka years ago and most likely advanced synchronously with the Puget lobe.

Conditions during advance of the Cordilleran Ice Sheet seem to have been similar for the Double Bluff, Possession, and Fraser Glaciations. All spread outwash in front of the advancing terminus, burying pre-existing topography before overriding it. The outwash was then overridden and deeply scoured in places. Following the extensive scouring, Vashon till was deposited as a blanket, mantling the just-scoured topography. The relationship of the till to the scoured topography infers that scouring took place during the Vashon maximum and till deposition followed, probably as the ice began to wane.

Considering the radiocarbon dates and the distance traveled by the ice lobes, the rate of advance of the terminus can be calculated as $80-110 \mathrm{~m} / \mathrm{yr}\left(250-350^{\prime} / \mathrm{yr}\right)$. Using several glaciological assumptions and supposing that the rate of advance was half that of the rate of retreat, Booth $(1986,1987)$ estimated the rate of advance of the terminus at $80-200 \mathrm{~m} / \mathrm{yr}$.

\section{CONFIGURATION OF THE ICE SHEET AT GLACIAL MAXIMUM}

Deposits at the margins and termini of the Double Bluff and Possession glaciers have been largely buried by younger deposits, so that the configurations of those glaciers are difficult

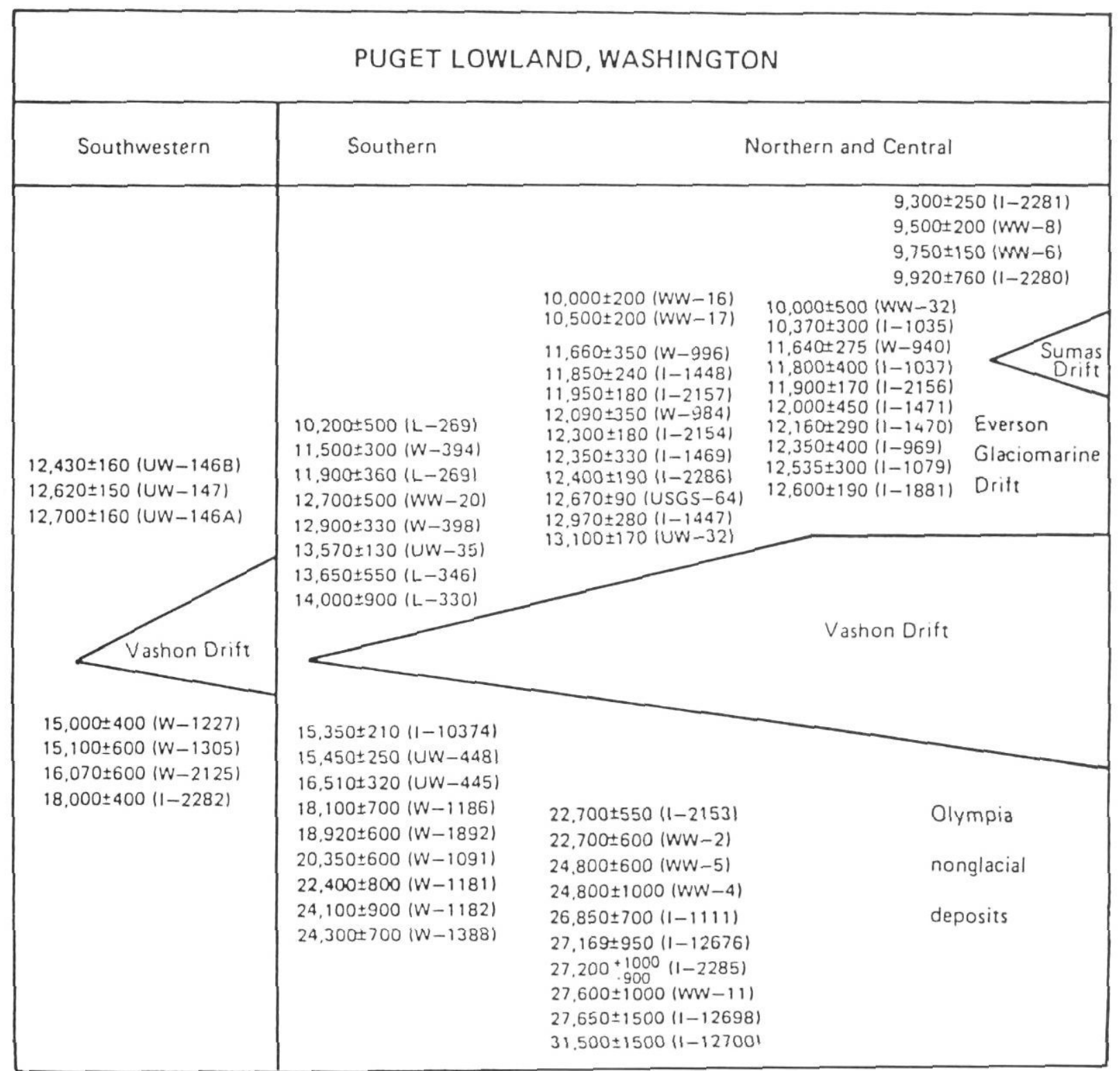

FIGURE: 8. Radiocarbon chronology of the Fraser Glaciation in the Chronologie au radiocarbone de la Glaciation de Fraser, dans les basPuget Lowland. ses terres de Puget. 
to reconstruct. Carson (1970) and Lea $(1983,1984)$ have mapped drift extending from under Vashon Drift in several places, but the age of these deposits has not been established. However, the margins of the Vashon glacier can be fairly accurately established (Cary and Carlston, 1937; Mackin, 1941; Carson, 1970; Crandell, 1963; Easterbrook, 1969). The height of the glacier surface can be approximated using the maximum elevation of glacial erratics in the Cascade and Olympic Mts. (Easterbrook, 1963). Compilation of these data resulted in the reconstruction shown in Figure 9, originally published by Easterbrook (1979) and later replicated by Thorson (1980). Elevations of the ice surface are shown as contours, which approximate the ice thickness, and give a surface slope of about $60 \mathrm{~cm} / \mathrm{km}$, comparable to modern temperate glaciers.

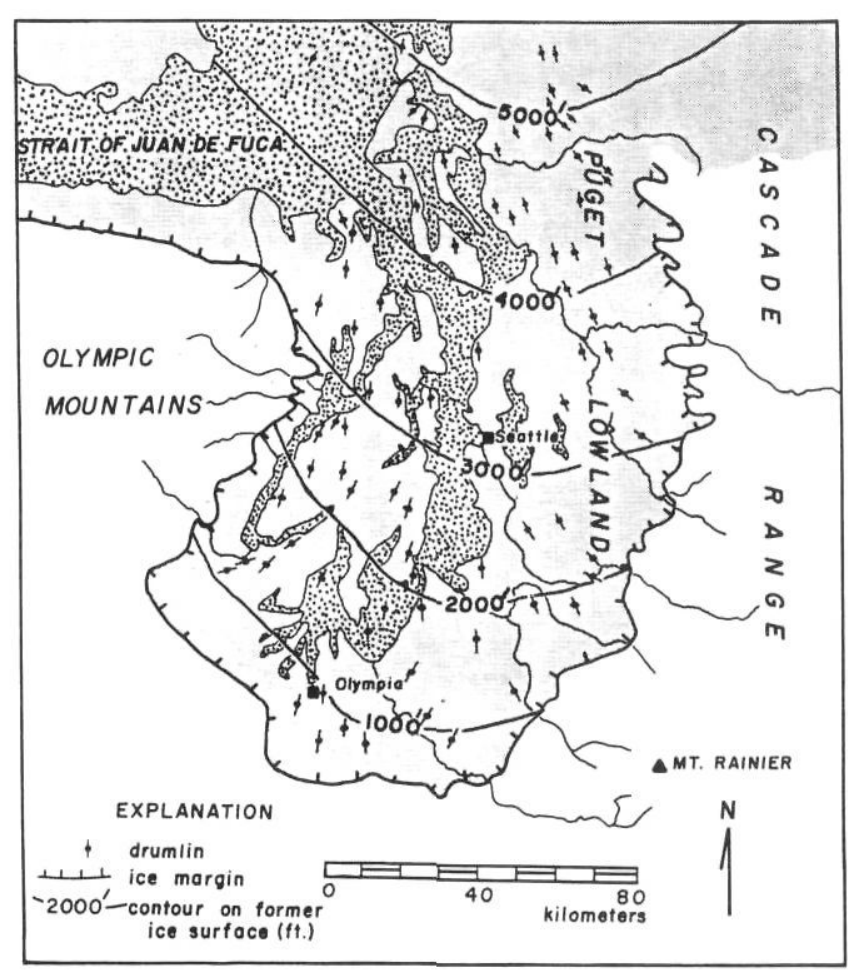

FIGURE 9. Reconstruction of the Puget lobe of the Vashon glacier at $\sim 15,000$ years BP (after Easterbrook, 1979).

Reconstitution du lobe de Puget, appartenant au glacier Vashon, vers 15 ka BP (d'après Easterbrook, 1979).
Using these data, Booth $(1986,1987)$ estimated the velocity of basal sliding of the ice sheet at $650 \mathrm{~m} / \mathrm{yr}$, based on an assumed equilibrium line altitude (ELA), comparison of glaciological parameters with modern alpine glaciers, and assuming that plastic flow accounted for only $2 \%$ of the total glacier movement.

\section{SCOURING BY THE VASHON GLACIER}

Since the early work of Bretz (1913) in the Puget Lowland, much speculation has centered around the origin of the deep troughs now occupied by Puget Sound and adjacent waterways, in some places, extending to depths of several hundred meters below present sea level. Bretz (1913) pointed out that the problem of their origin is far from simple glacial scouring. However, in a few places, some estimates of the minimum depth of scouring by Vashon ice can be made, based on the relationship between Vashon till and relief cut into the underlying advance outwash. For example, in sea cliffs along northern Whidbey Island, Vashon till rests on advance Vashon outwash (Esperance sand) at elevations up to $75 \mathrm{~m}$ above present sea level and cuts across the outwash to and below sea level (Figs. 10 and 11). Because the outwash surface must have been level at the time of its deposition, the truncation by Vashon till means that at least $75 \mathrm{~m}$ of glacial scouring must have taken place after deposition of the outwash but before deposition of the till (Easterbrook, 1968).

The relationship between Vashon till and the underlying advance outwash is of special interest because the till is draped across the eroded surface of the outwash in a manner such that the deep erosion into the outwash must have been completed prior to till deposition. This infers that the glacier scour most likely took place during the Vashon maximum and subglacial conditions subsequently changed to allow deposition of the till, perhaps as the vigor of the ice waned.

\section{NATURE OF THE RETREAT OF THE CORDILLERAN ICE SHEET}

\section{DOUBLE BLUFF DEGLACIATION}

Although exposures of Double Bluff Drift are limited, most include glaciomarine drift overlying till. Examples occur at the type locality (Double Bluff), Possession Point, Ebeys Landing,
FIGURE 10. Cross-sections of Vashon till truncating advance Vashon outwash, north of Penn Cove, Whidbey Island.

Coupes dans le till de Vashon tronquant du matériel d'épandage fluvio-glaciaire, au nord de Penn Cove, dans Whidbey Island.
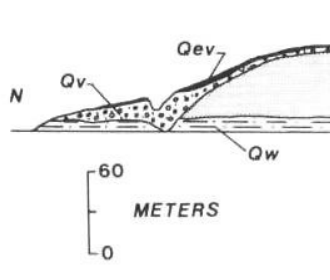

$\int^{0}$

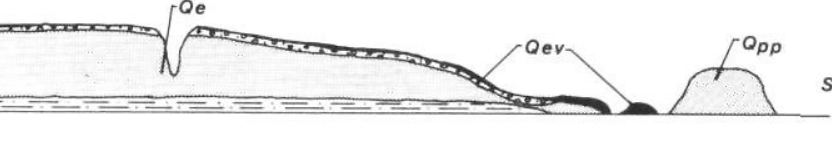

Qev-Everson Glaciomarine Drift

Qv - Vashon till

Qe-Esperance Sand

Ow-Whidbey $F m$.

0

Qpp - Point Partridge Gravel

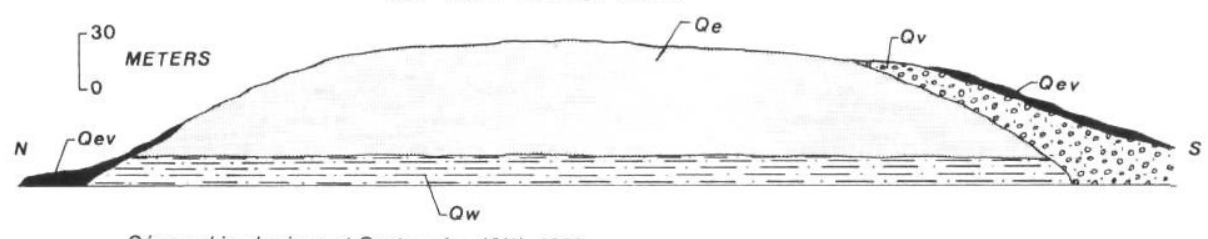




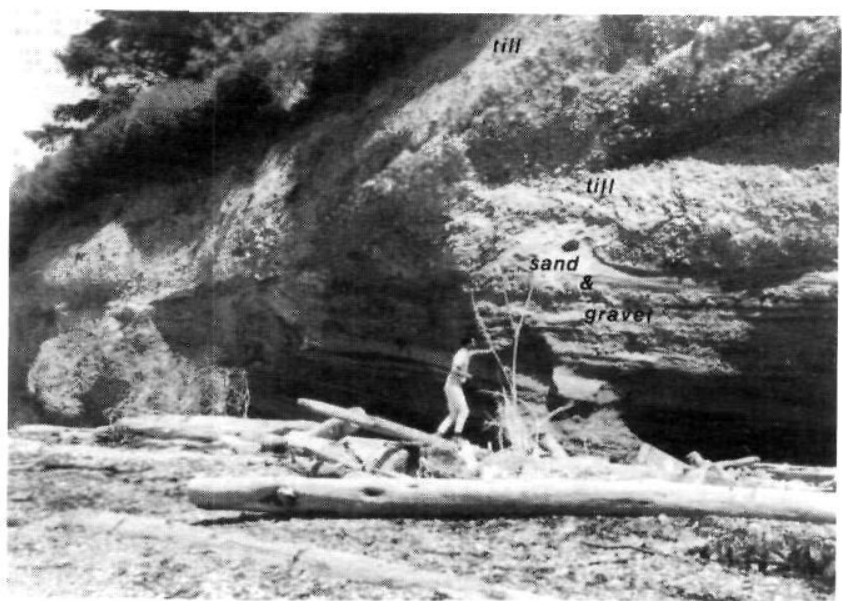

FIGURE 11. Vashon till cutting across older sediments north of Lagoon Point, Whidbey Island.

Till de Vashon coupant des sédiments plus anciens, au nord de Lagoon Point, dans Whidbey Island.

and Foulweather Bluff. The significance of these localities is that glaciomarine conditions immediately followed deposition of till during the recessional phase of the Double Bluff glaciation, and little or no outwash was associated with deglaciation.

Double Bluff glaciomarine drift typically consists of a massive, poorly sorted, stony, silt/clay diamicton (Easterbrook et al., 1967). Marine shells and shell fragments occur sporadically, but are not as abundant as in younger glaciomarine drifts, perhaps due in part to the paucity of exposures of Double Bluff Drift. The lithology of pebbles, cobbles, and boulders in the glaciomarine drift is similar to that found in Double Bluff till, confirming a British Columbia source. The combination of erratic lithologies and marine shells indicate a glaciomarine origin for these diamictons.

The age of the Double Bluff glaciomarine drift is based on amino acid analyses and thermoluminescence measurements. The estimated amino acid age, based on leucine $D / L$ ratios, is 111 to 178 ka years BP (Blunt et al., 1987). Preliminary thermoluminescence measurements give comparable ages (Berger, personal communication).

The glaciomarine drift that immediately overlies Double Bluff till and the absence of post-till outwash or other subaerial glacial deposits of Double Bluff age leads to the inference that conditions during deglaciation were similar to those of the Fraser Glaciation where more detail is preserved. Although this interpretation is consistent with all presently known exposures of Double Bluff Drift, it should be considered as tentative because of the limited number of exposures above sea level.

\section{POSSESSION DEGLACIATION}

Exposures of Possession Drift are commonly truncated by erosion and are typically lenticular, pinching out laterally within a kilometer. However, a number of relatively complete sections occur where Possession till is directly overlain by glaciomarine drift containing marine fossils (Fig. 12), rather than by recessional outwash deposits.

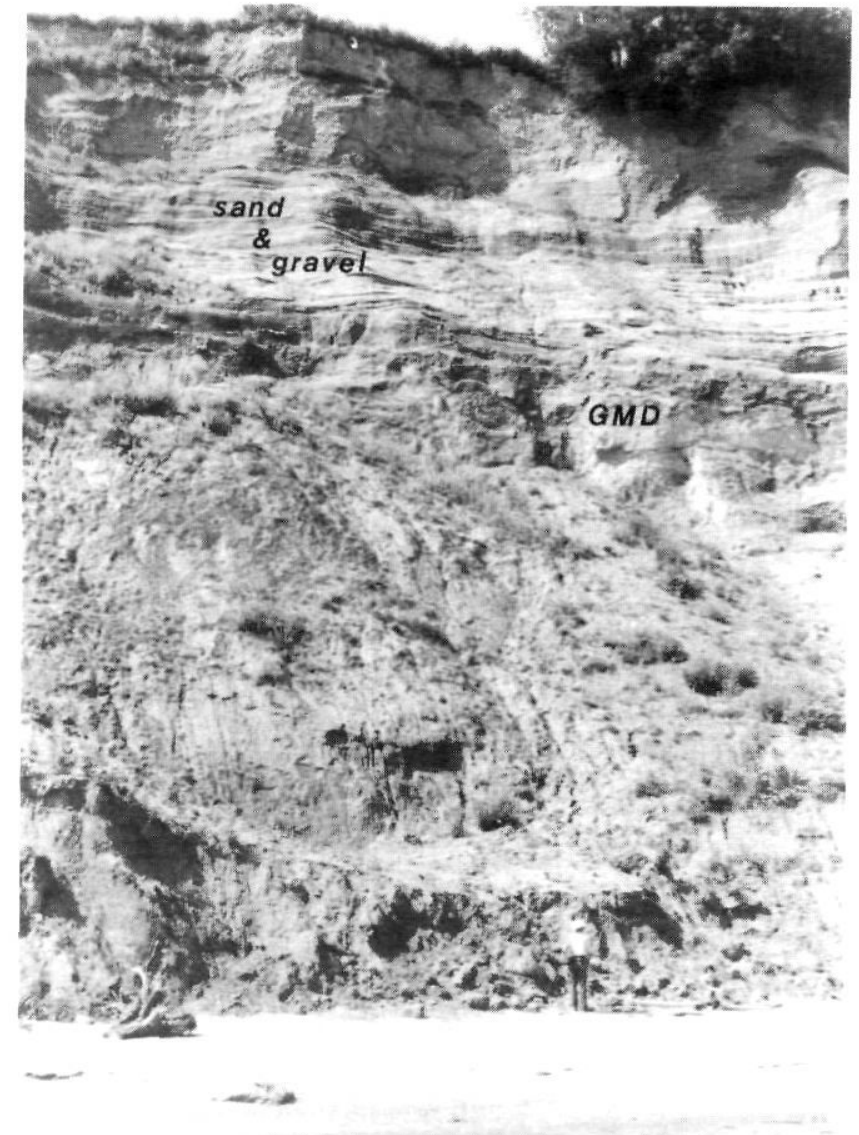

FIGURE 12. Possession glaciomarine drift (GMD) overlying Possession till at Point Wilson. The glaciomarine drift is overlain by Vashon advance outwash (sand and gravel).

A Wilson Point, till de Possession recouvert de dépóts glacio-marins de Possession (GMD). Du matériel d'épandage fluvio-glaciaire (sables et graviers) recouvre à son tour ces dépóts glacio-marins.

Possession glaciomarine drift usually consists of a massive, poorly sorted, till-like diamicton (Easterbrook et al., 1967; Easterbrook, 1968). Unbroken marine shells are more common than in Double Bluff glaciomarine drift, and in some places, occur in great abundance. The lithology of pebbles, cobbles, and boulders in the glaciomarine drift is similar to that found in the underlying till, indicating a British Columbia source. The combination of British Columbia lithologies and intact marine shells indicate a glaciomarine origin for Possession diamictons.

No recessional outwash deposits are known to occur on top of Possession till. However, Possession Drift in the central Puget Lowland is typically lenticular and its stratigraphic position may be represented by an incomplete section or only by an unconformity. In those places where only Possession gravel occurs in an exposure, whether it is an advance outwash or a recessional outwash is uncertain. However, in exposures with more complete sections, the glaciomarine drift invariably rests directly on till with no recessional outwash, inferring that where only Possession gravel is exposed, it is probably advance outwash.

The significance of the more-complete sections is that glaciomarine conditions immediately followed deposition of 


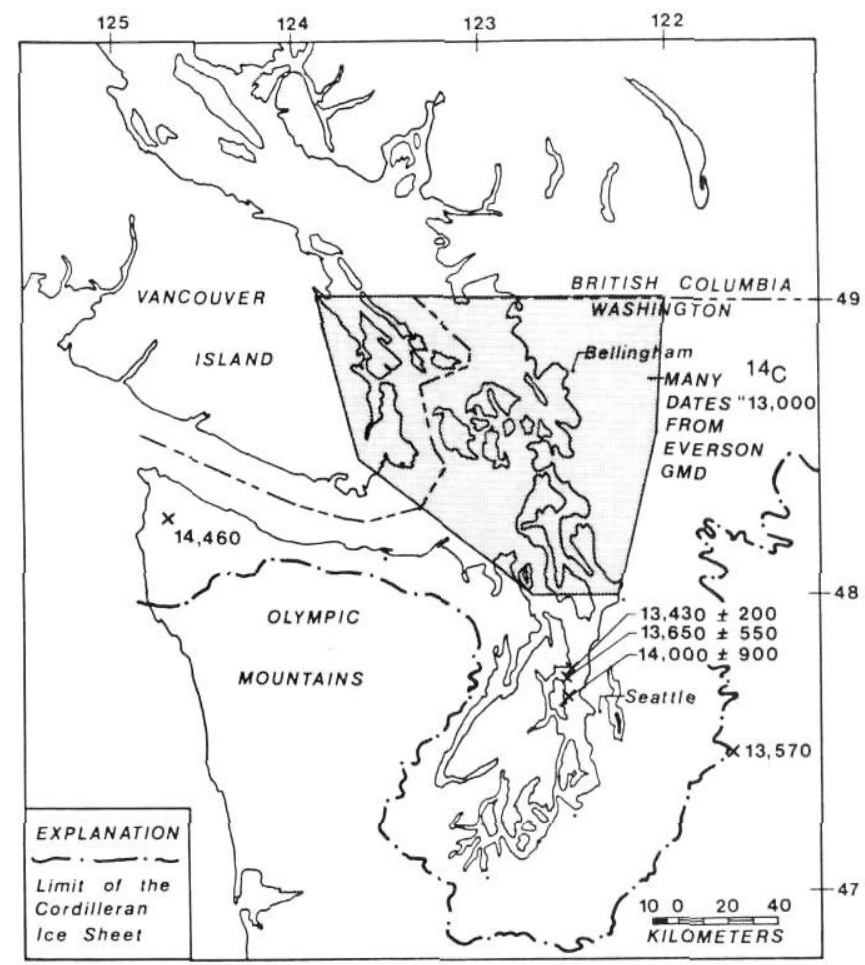

FIGURE 13. Limiting radiocarbon dates for recession of the Vashon Puget lobe in the southern Puget Lowland.

Dates limites, déterminées au radiocarbone, du recul du lobe de Puget, dans le sud des basses terres de Puget.

Possession till and, like the Double Bluff and Fraser deglaciations, constituted the dominant mode of deglaciation in the Puget Lowland.

\section{FRASER DEGLACIATION}

The terminal zone of the Puget Lobe lacks a well-defined end moraine, and is marked only by small, segments of end moraines, extensive outwash deposits, and kame-kettle complexes (Bretz, 1913; Mackin, 1941; Crandell, 1963; Noble and Wallace, 1966; Carson, 1970; Porter and Carson, 1971; Lea, $1983,1984)$. Like many of the glaciers elsewhere in the world, the Puget lobe underwent sudden, rapid, large-scale recession and down-wasting between 13 and 14.5 ka years ago (Fig. 13). It retreated from its terminal maximum position by backwasting, depositing recessional outwash and proglacial lacustrine sediments in lakes impounded by the receding ice front (Bretz, 1913; Curran, 1965; Deeter, 1979; Waitt and Thorson, 1983).

The ice sheet had retreated from the Seattle area before $14,000 \pm 900$ (L-330), 13,650 \pm 550 (L-346A) and 13,430 \pm 200 years (Rigg and Gould, 1957; Leopold et al., 1982). Wood in ice-dammed lake sediments east of Seattle, radiocarbon dated at 13,570 \pm 130 (UW-35) years may have been deposited shortly after the Puget lobe withdrew from the area, but before the lake drained completely.

Timing of the retreat of the Juan de Fuca lobe from its terminal position is limited by radiocarbon dates of $14,460 \pm 200$ (Y-2452) years from a bog on Vashon Drift near the western margin of the Strait of Juan de Fuca, and dates of: 13,380 \pm 250 (RL-140), 13,100 \pm 180 (Y-2449), 13,080 \pm 260

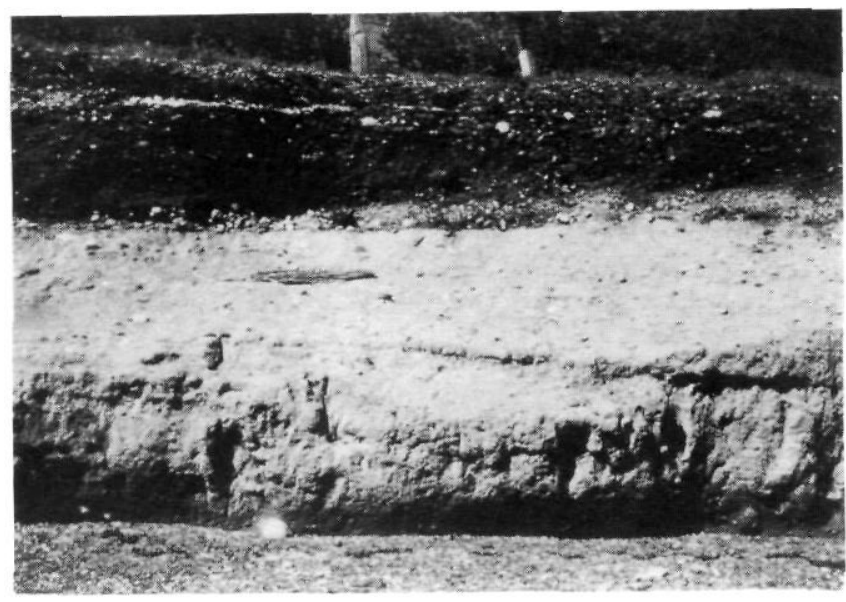

FIGURE 14. Till-like Everson glaciomarine drift west of Bellingham. Dépôts glacio-marins d'Everson ressemblant à du till, à l'ouest de Bellingham.

(Y-2450), 13,010 \pm 240 (RL-139), 12,020 210 (RL-138) from wood in till at five localities in the terminal zone of the Juan de Fuca lobe (Heusser, 1973a, 1973b, 1982). Bottom sediments in the Strait of Juan de Fuca, dated at 14,400 \pm 400 and $13,150 \pm 400$ years (Anderson, 1968), were deposited during recession of the lobe, and basal peat from a mastodon site along the western portion of the strait has been dated at $12,100 \pm 310$ (WSU-1866) years (Peterson et al., 1983).

Rapid thinning of Vashon ice after the terminus had receded north of Seattle allowed marine water through the Strait of Juan de Fuca to flood the lowland, floating the remaining ice and depositing Everson glaciomarine drift over a large area in the central and northern Puget Lowland and San Juan Islands (Easterbrook, 1963, 1966a, 1966b, 1968, 1969, 1971, 1976a, 1976d, 1979, 1986, 1987) and British Columbia (Armstrong, 1977, 1981; Armstrong and Brown, 1954; Armstrong and Hicock, 1976; Armstrong et al., 1965, 1985).

The glaciomarine sediments consist largely of poorly sorted diamictons (Fig. 14) deposited when melting of floating ice released rock debris which accumulated on the sea floor. Unbroken, articulated marine shells, some in growth positions, indicate that the glaciomarine drift represents in situ deposition (Fig. 15) (Easterbrook, 1963, 1982). More than 80 radiocarbon dates from marine shells in the glaciomarine drift in Washington and British Columbia fix the age of the Everson glaciomarine drift at 11.5 to $13.5 \mathrm{ka}$, making it a valuable stratigraphic marker over an area of approximately $18,000 \mathrm{~km}^{2}$.

The origin of the glaciomarine drift from floating ice in sea water was first recognized in Washington by Easterbrook (1963, 1966a, 1966b, 1969) and by Armstrong and Brown (1954) in British Columbia. However, whether the floating ice was berg ice, shelf ice, sea ice or a retreating, calving ice-front has long been equivocal. Armstrong and Brown (1954) suggested that the floating ice responsible for deposition of the glaciomarine drift may have been shelf ice, berg ice, or sea ice and that some of the sediment may have been eroded from previously deposited till and redeposited by submarine slides and turbidity currents. They left the question open as to which of these was predominant. Evaluation of evidence for the 


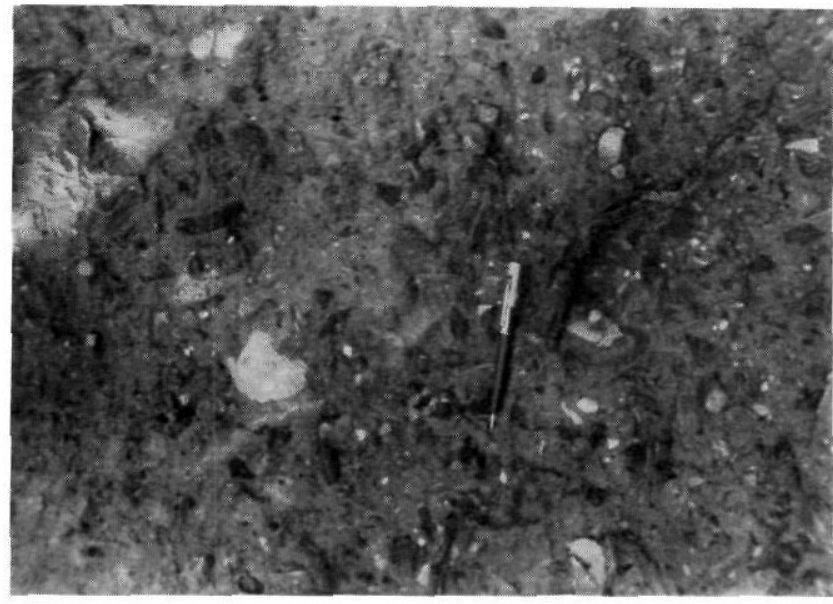

FIGURE 15. Articulated marine mollusc shells in till-like Everson glaciomarine drift, San Juan Island.

Coquillages marins articulés, dans les dépóts glacio-marins d'Everson, dans San Juan Island.

depositional environment of glaciomarine drift in the northern Puget Lowland led Easterbrook (1963) to conclude that (1) sea ice would not explain the numerous erratic pebbles, cobbles, and boulders in the glaciomarine drift, (2) the submarine slopewash concept of Armstrong and Brown was not applicable to the glaciomarine drift in the Puget Lowland because it implies sporadic deposition within normal stratified marine sediments, (3) the relatively uniform distribution of coarse material in the glaciomarine drift indicates a fairly continuous rain of unsorted material, compatible with shelf or berg ice, and (4) the living environment of fossil shells suggested water depths of $-35-45 \mathrm{~m}$. The problem of distinguishing between deposition from shelf or berg ice remained perplexing for more than a decade, largely because of the large area covered by Everson glaciomarine drift $\left(\sim 18,000 \mathrm{~km}^{2}\right)$. Over such a vast area, deposition from berg ice would seemingly lead to "nests" of coarse debris interbedded as lenses in normal marine sediments, and yet shelf ice seemed unlikely in such a temperate environment. Thus, most papers on glaciomarine drift published up to ab out 1980 left the question open.

Pessl et al. (1981) and Domack (1983) suggested that the Everson glaciomarine drift was deposited by ice calving from the front of a progressively northward-retreating, backwasting ice terminus. This mechanism of origin requires northward transgressive deposition of the glaciomarine drift over a distance of more than $170 \mathrm{~km}$ from the southern limit of the glaciomarine drift to the northern limit in British Columbia and would mean that the glaciomarine drift in the northern part of the region should be younger than glaciomarine drift farther south. However, as clearly shown in Figures 16 and 17, the fatal flaw in this concept is that the large numbers of radiocarbon dates from Everson glaciomarine drift do not become progressively younger northward. In fact, most of the oldest ${ }^{14} \mathrm{C}$ dates from the glaciomarine drift are from the northernmost part of the region (Fig. 17).

Most of the evidence presented by Domack (1983) for the calving ice front hypothesis is based on sedimentological features in the Everson glaciomarine drift near the middle of

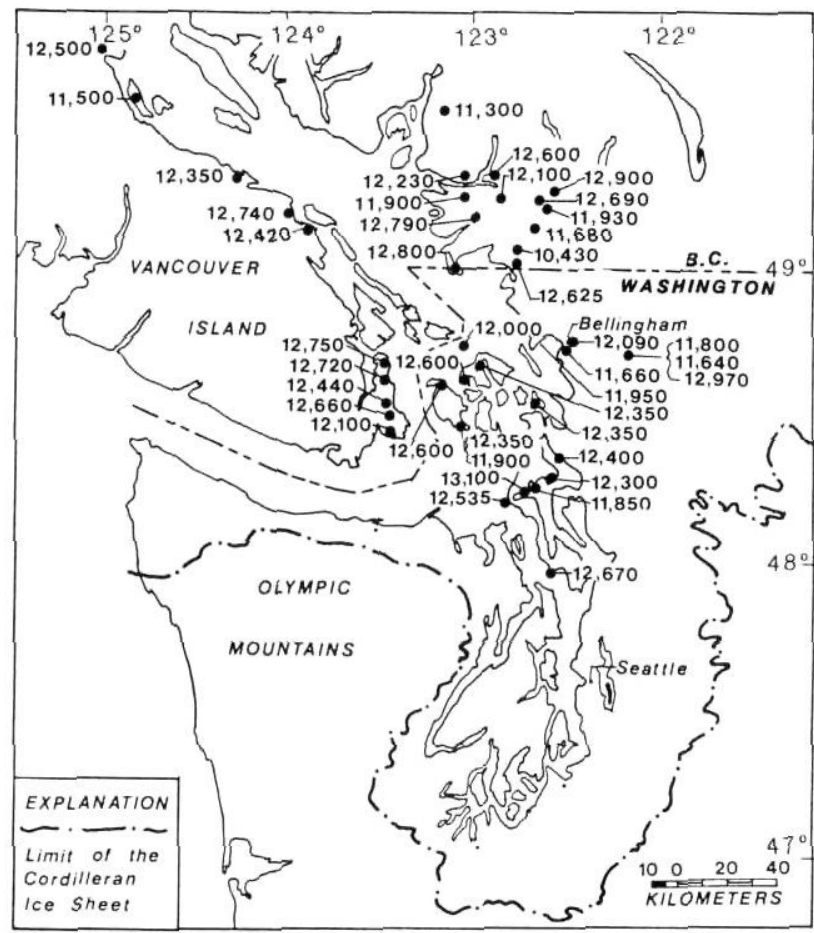

FIGURE 16. Distribution of radiocarbon dates from Everson glaciomarine drift. Note the even distribution of old and young ages from north to south. Some of the oldest dates in British Columbia (Fig. 17) are not shown because their location is not known.

Datations au radiocarbone effectuées dans les dépóts glacio-marins d'Everson. À noter l'égale répartition des dates, anciennes et récentes, du nord au sud.

SOUTH

NORTH

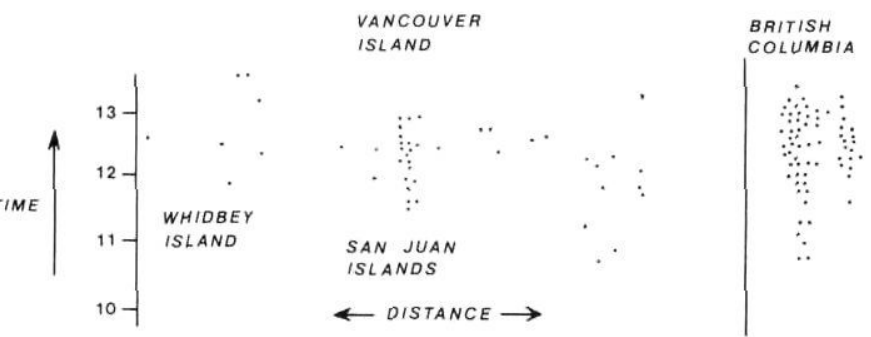

FIGURE 17. Radiocarbon dates from Everson glaciomarine drift plotted against latitude. Many of the oldest dates are from British Columbia and the age range there spans the entire age range of glaciomarine drift to the south, providing evidence against the backwasting, calving terminus theory for the origin of the glaciomarine drift. The British Columbia radiocarbon dates are from several labs, including both Canadian and U.S. laboratories.

Datations au radiocarbone des dépóts glacio-marins d'Everson par rapport à la latitude. Nombre de dépóts parmi les plus anciens se trouvent en Colombie-Britannique; il y a là des dépóts glacio-marins de tous les áges, des plus anciens aux plus récents, ce qui contribue à infirmer l'hypothèse selon laquelle un front qui vélait aurait été à l'origine des dépóts glacio-marins. Les datations au radiocarbone ont été effectuées dans plusieurs laboratoires, tant au Canada qu'aux États-Unis.

Whidbey Island where an unusually diverse set of lenses and interbeds occurs within the glaciomarine drift. Although these sedimentary features do not prove a calving origin for the sediments, they are consistent with such an interpretation, and 


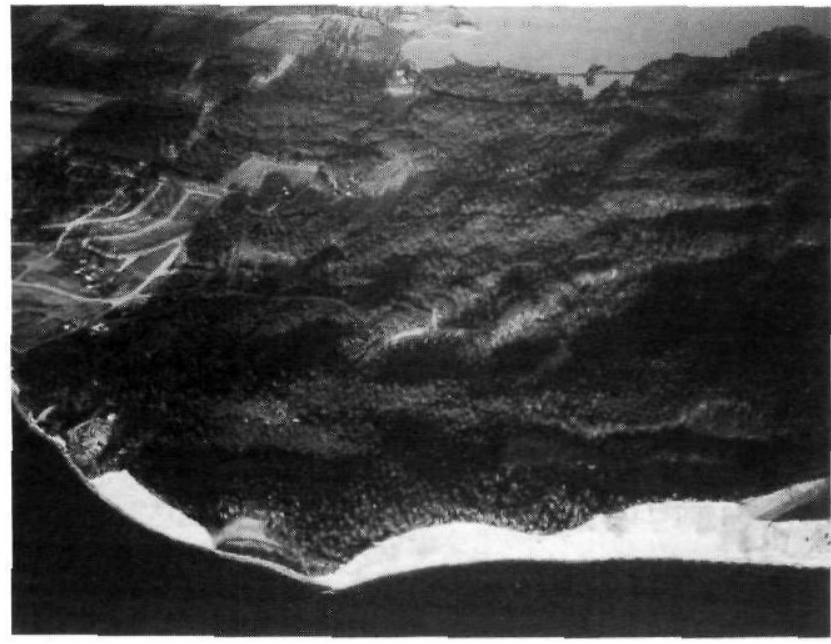

FIGURE 18. Late Vashon, deeply kettled, stagnant-ice topography at Penn Cove, Whidbey Island. Some of the kettles are $\sim 30 \mathrm{~m}$ deep. Sea cliffs in the foreground expose Partridge Point gravel with welldeveloped foreset beds containing shell fragments. Everson glaciomarine drift laps up onto the gravel in the bluffs at the left edge of the photo.

À Penn Cove, dans Whidbey Island, topographie marquée par la glace stagnante. Certaines dépressions ont quelque $30 \mathrm{~m}$ de profondeur. Au premier plan, les parois des falaises révèlent des graviers de Partridge Point qui présentent des lits deltaïques frontaux renfermant des fragments de coquillages. À gauche, sur la photo, les dépóts glacio-marins d'Everson chevauchent les graviers des escarpements.

Domack has chosen to interpret them as such. His approach was to construct detailed lithofacies maps of glaciomarine drift and attempt to match them with hypothetical sedimentary environments. In this way, Domack paints conjectural depositional environments, which, although not conclusively proven, may well be correct. Unfortunately, even if the interpretation is correct, the location chosen by Domack for his study is unique in the entire Puget Lowland because it is the only place where glaciomarine drift was deposited directly upon the deeply kettled, stagnant-ice, Partridge Point gravel of the rapidlydeteriorating Vashon glacier (Fig. 18) (Easterbrook, 1968). The Everson glaciomarine drift caps the Partridge Point gravel, but the heavily-kettled topography remains preserved. The significance of the relationship between the glaciomarine drift and the Partridge Point gravel is: (1) the stagnant ice features are not consistent with the actively-calving, retreat ice terminus postulated by Domack, and (2) nowhere in the rest of the $18,000 \mathrm{~km}^{2}$ of Everson glaciomarine drift are these unique features replicated. Thus, even if the sedimentary environments hypothesized by Domack for deposition of the glaciomarine drift are correct for central Whidbey Island, they have no counterparts elsewhere in the Puget Lowland.

Finally, a third line of evidence argues strongly against the calving-ice model. In the northern Puget Lowland, the fluvial Deming sand separates two members of the Everson glaciomarine drift, the Kulshan and Bellingham glaciomarine drifts (Fig. 19) (Easterbrook, 1963). The importance of the Deming sand is that the conclusive evidence of its nonmarine origin means that the Bellingham glaciomaririe drift was deposited upon fluvial sediments over some $2300 \mathrm{~km}^{2}$ with no till or other evidence of a readvance of the Cordilleran Ice Sheet to provide

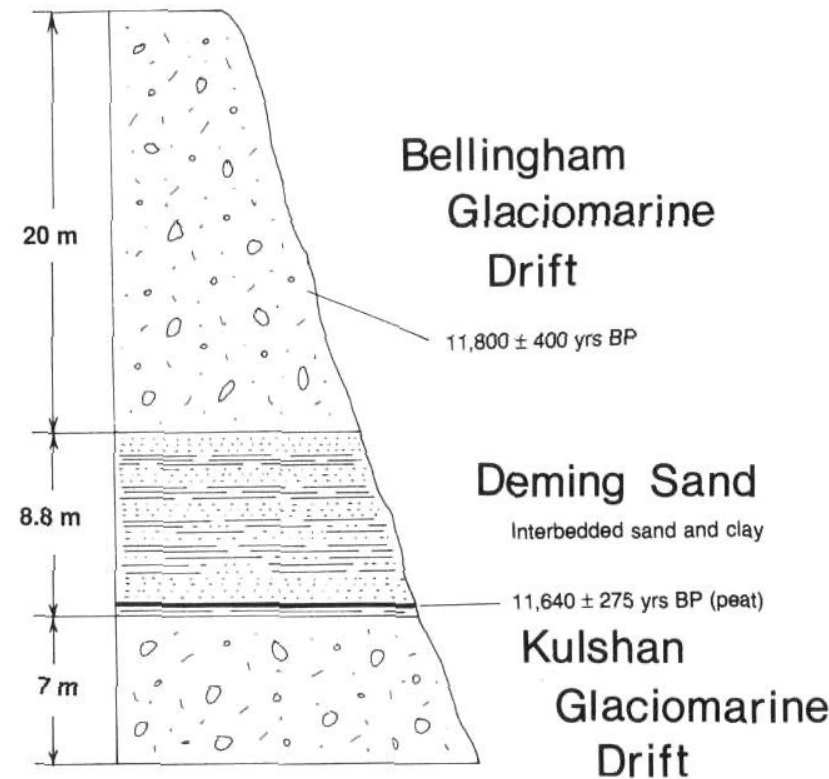

FIGURE 19. Type locality of the Everson glaciomarine drift at Cedarville. The peat bed at the base of the Deming sand contains several in situ rooted stumps. Marine mollusc shells in the Kulshan glaciomarine drift at a nearby locality were radiocarbon-dated at $12,970 \pm 280$ (1-1447). Other dates are shown on the figure.

Site de référence dans les dépôts glacio-marins d'Everson, à Cedarville. Le lit de tourbe, à la base des sables de Deming, renferme plusieurs souches enracinées sur place. Les coquillages marins contenus dans les dépôts glacio-marins de Kulshan, non loin de là, ont été datés à 12970 ans \pm 280 (I-1447). D'autres dates sont données sur la figure.

a calving terminus. Perhaps the most critical point here is the evidence for the nonmarine origin of the Deming sand at its type locality where it is underlain by Kulshan glaciomarine drift and overlain by Bellingham glaciomarine drift. To settle the issue of its nonmarine origin once and for all, the following evidence is presented:

(1) The Deming sand is a fluvial deposit with abundant crossbedding and channeling in the sediment.

(2) The base of the Deming sand contains a welldeveloped peat bed that contains abundant pollen of pine and other non-sait tolerant species and lacks pollen of any marine species.

(3) Three in situ tree stumps have been found in the basal peat bed. These tree stumps have intact root systems so they could not have been transported into the peat bed from elsewhere.

(4) The Deming sand is almost completely monolithologic, consisting almost entirely of phyllite grains derived from the Darrington phyllite which only outcrops many kilometers upstream from the type locality. This means that the sand must have been fluvially derived. It could not be marine because no source for this lithology is available for marine erosion and the sediments are not deltaic.

(5) The overlying Bellingham glaciomarine drift contains abundant erratic lithologies from British Columbia, indicating that it must have come from Cordilleran ice and not from a local source upvalley. 
(6) No evidence of any marine phenomena has ever been found associated with the Deming sand at its type locality

Deposition of the Bellingham glaciomarine drift directly on the nonmarine Deming sand means that the return of glaciomarine conditions was not accompanied by a readvance of the Cordilleran Ice Sheet over the area that would provide a calving, backwasting glacier terminus.

To summarize the compelling evidence against the backwasting, calving, terminus model for the origin of the glaciomarine drift:

(1) Abundant ${ }^{14} \mathrm{C}$ dates from the glaciomarine drift demonstrate virtually simultaneous deposition of the glaciomarine drift over a very large area, and northward, time-transgressive deposition is not possible without throwing out virtually all of the many ${ }^{14} \mathrm{C}$ dates.

(2) Stagnant ice deposits closely related in time to the glaciomarine drift at the sites used by Domack (1983) as evidence of a calving terminus are unique to the entire Puget Lowland, so even if the calving terminus concept is applicable at those sites, it is not relevant to the entire Puget Lowland.

(3) These stagnant ice deposits argue against an activelycalving, backwasting terminus of the Cordilleran Ice Sheet just prior to deposition of the glaciomarine drift.

(4) Conclusive evidence for the nonmarine origin of the Deming sand between the Kulshan and Bellingham members of the Everson glaciomarine drift means that Cordilleran ice, needed to provide a calving, backwasting glacier terminus, was absent from the area immediately prior to deposition of the glaciomarine drift.

The overlapping of such a large number of radiocarbon dates distributed over such a wide area and the occurrence of many old dates in the northern outcrops and young dates in the southern outcrops invalidates the Domack transgressive, calving-ice-front model for deposition of the Everson glaciomarine drift. Deposition from shelf ice is considered unlikely in view of paleoecological conditions suggested by diatoms and foraminifera in the glaciomarine drift (Crandall, 1979). Much of the deposition of glaciomarine drift during the earliest phases probably resulted from floating of rapidly thinned, debris-laden ice, followed by deposition largely from abundant berg ice (Armstrong and Brown, 1954; Armstrong, 1981; Easterbrook, 1963, 1969, 1971).

If the glaciomarine drift in the Puget Lowland could not have been deposited from a backwasting, calving terminus of the Cordilleran Ice Sheet, the intriguing question remains, what was the environment of sedimentation? Deposition of the glaciomarine drift from shelf ice poses the problem of maintaining shelf ice over such a large area in a temperate latitude. The berg-ice model suffers from the problem of how to get enough ice bergs over such a huge area with enough consistency to supply a more-or-less continuous rain of coarse material. A potentially attractive model is that the sudden, dramatic climatic warming at about $14 \mathrm{ka}$ years $\mathrm{BP}$, recognized from the ${ }^{18} \mathrm{O} /{ }^{16} \mathrm{O}$ record in deep sea and ice cores, caused such rapid thinning of the Cordilleran Ice Sheet that once the terminus of the glacier had backwasted northward past the latitude of Seattle, the remainder of the ice sheet was so thin that it stagnated over the northern and central Puget Lowland at the same time as marine water entered from the Strait of Juan de Fuca and floated the greatly thinned remnant of the ice sheet. This would supply an ice cover over the region, not in the same sense as a typical ice shelf, and the ice would likely have a concentrated debris load. As the remaining floating ice disintegrated the area could have been covered with large masses of berg ice. This model, although somewhat similar to the shelf ice/berg ice model, differs significantly and circumvents many of the problems associated with it. It also accounts for the virtual simultaneous deposition of glaciomarine drift throughout the region.

\section{ISOSTATIC AND EUSTATIC SEA LEVEL CHANGES IN THE CENTRAL AND NORTHERN PUGET LOWLAND}

Evidence of late and postglacial relative sea level changes may be found in marine terraces in the central and northern Puget Lowland and the San Juan Islands (Easterbrook, 1969, 1979). The relationship between isostatic depression during the glacial maxima, postglacial isostatic rebound, and postglacial eustatic sea level rise is complex, made even more complicated by the possibility of tectonic warping superimposed upon the isostatic and eustatic changes. Elevation of Everson glaciomarine drift and marine terraces provide constraints on relative sea level changes, but the more difficult part lies in sorting out the isostatic, eustatic, and tectonic contributions to the total change.

In the central Puget Lowland and San Juan Islands, maximum elevations of glaciomarine drift rise somewhat sporadically from 5-10 $\mathrm{m}$ at the southern end of Whidbey Island to $\sim 50 \mathrm{~m}$ at the northern end of the island. The island is elongate in a north-south direction and excellent sea cliff exposures along the west coast allow tracing of the glaciomarine drift as it laps up against the higher parts of the island, thins, and finally feathers out. Unfortunately, the glaciomarine drift is difficult to trace continuously through the middle of the island, so what emerges is a somewhat incomplete picture, but seems to portray a level that rises to the north as might be expected as a result of isostatic rebound. Marine terraces at about $60 \mathrm{~m}$ are widespread in the northern part of the island (Easterbrook, $1966,1968)$ and although not directly dated, stratigraphic and morphologic relationships suggest that they are closely related in time to deposition of the Everson glaciomarine drift and the Partridge Point gravel discussed above. Late glacial marine terraces 70-80 m above present sea level and glaciomarine drift also occur in the San Juan Islands (Bretz, 1913; Easterbrook, 1969).

Multiple marine strandlines $30 \mathrm{~m}$ below the maximum level of Everson glaciomarine drift on the mainland northwest of Whidbey Island (Fig. 20) occur at elevations up to $67 \mathrm{~m}$ above present sea level (Easterbrook, 1979). The lowest of these strandlines occurs about $35 \mathrm{~m}$ above sea level. All of the strandlines are truncated by an outwash channel and terrace about $30 \mathrm{~m}$ above sea level (Fig. 20). The outwash terrace must belong to the Sumas Stade of the Fraser Glaciation, ${ }^{14} \mathrm{C}$ dated elsewhere at about $10-11,5$ ka years BP, so the age of the strandlines must be older than that but younger than the Everson glaciomarine drift. A limiting age for similar strandlines nearby is given by a radiocarbon date of $11,700 \pm 110$ 
FIGURE 20. Multiple marine strandlines below the highest Everson glaciomarine drift, truncated by Sumas outwash channels, north of Mount Vernon.

Nombreuses lignes de rivage sous les dépóts glacio-marins d'Everson les plus hauts, que viennent tronquer des couloirs d'épandage fluvio-glaciaire de Sumas, au nord du mont Vernon.

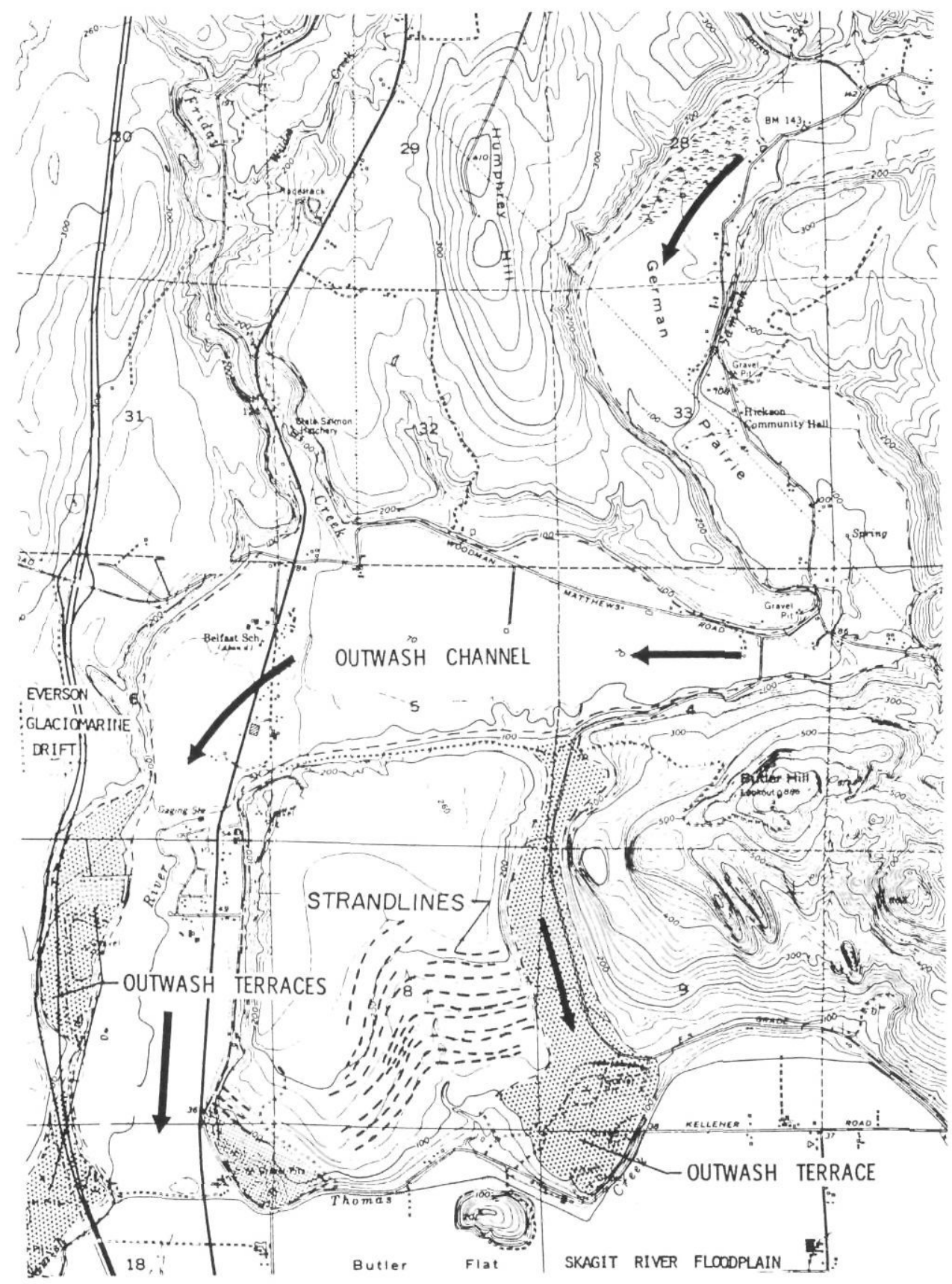

(USGS-342) from basal peat at $47 \mathrm{~m}$ (Siegfried, 1978). Foreset-bedded deltaic sand and gravel comprising the outwash terrace in Figure 20 was incised by meitwater from about $30 \mathrm{~m}$ above present sea level to less than six meters during the late Sumas Stade (Easterbrook, 1979). The significance of these relationships is that isostatic rebound of this part of the lowland seems to have been quite rapid in late to early-post Fraser time, followed by rates approximately comparable to eustatic sea level rise for most of the rest of the Holocene.

In the northern Puget Lowland, the situation is considerably more complicated. There, Everson glaciomarine drift consists of three members, the Kulshan glaciomarine drift, which rests on Vashon till, overlain by the fluvial Deming sand and the Bellingham glaciomarine drift (Easterbrook, 1963). The rela- tionships between these deposits, discussed above, and maximum elevations of outcrops permits reconstruction of relative land-sea level changes. The Kulshan glaciomarine drift contains marine fossils radiocarbon dated at 12,970 \pm 280 (I-1447) and extends to elevations of at least $75 \mathrm{~m}$ with water depths of approximately $30 \mathrm{~m}$, giving a sea level of about $105 \mathrm{~m}$ above present sea level. The Kulshan glaciomarine drift closely followed deposition of Vashon till, so the land was likely still isostatically depressed at that time. The Kulshan is overlain by the fluvial Deming sand containing basal peat radiocarbon dated at $11,640 \pm 275(\mathrm{~W}-940)$ and, graded to beach deposits to the west at about 5-10 m above present sea level. Thus, at least $95-100 \mathrm{~m}$ of relative emergence must have occurred between deposition of Kulshan glaciomarine drift and deposition of Deming sand (105 m - 5-10 m). The Deming sand is 
overlain by Bellingham glaciomarine drift containing abundant marine fossils, radiocarbon dated at $11,800 \pm 400$ (I-1037) at the type locality, signalling a return to marine conditions. Outcrops of Bellingham glaciomarine drift extend to elevations of at least $180 \mathrm{~m}$ above present sea level and adding another $30 \mathrm{~m}$ for probable water depth gives a relative sea level of $210 \mathrm{~m}$ above present sea level, a relative submergence of $200 \mathrm{~m}$ from Deming to Bellingham time. Subaerial outwash channels of the Sumas Stade are cut into the Bellingham glaciomarine drift and meltwater deposits lap onto the glaciomarine dritt, indicating yet another relative sea level change of about $200 \mathrm{~m}$ in a very short period of time. Changes in relative sea level during the Holocene were relatively minor.

These dramatic late Fraser relative sea level changes in the northern Puget Lowland over a period of only about 2,000 years have for many years been informally referred to as the "yo yo effect" by the author. Although some have shown skepticism about them (Thorson, 1981), the physical evidence occurs in a single, large, riverbank exposure that requires no correlation or extrapolation of data, and the physical evidence seems irrefutable.

Sorting out the possible components in these short-term relative sea level changes begins with consideration of a combination of isostatic uplift of the land due to glacial unloading and eustatic rise of sea level near the close of the Pleistocene. Based on the maximum known altitude of erratics in the adjacent Cascade Range, the thickness of the Vashon glacier in the northern Puget Lowland at its maximum was $1600-1800 \mathrm{~m}$ (Easterbrook, 1963). Assuming full isostatic compensation, a crude estimate of the expected isostatic rebound would be approximately 550-600 m. However, radiocarbon dates of the duration of the Vashon glacier suggest that isostatic compensation was very likely not achieved (Easterbrook, 1963), so the total rebound was undoubtedly much less. The total range of eustatic sea level changes during the Pleistocene is generally believed to be $\sim 120 \mathrm{~m}$. Whether isostatic uplift or eustatic sea level rise prevailed at any particular time in the northern Puget Lowland can explain at least part of the emergence or submergence indicated in the stratigraphic record, but the resubmergence required to deposit the Bellingham glaciomarine drift and re-emergence to deposit Sumas outwash cannot be explained in this way.

The pattern of isostatic, eustatic, and tectonic events needed to explain the Everson sediments in the northern Puget Lowland is as follows:

(1) Glacial loading during the Vashon maximum depressed the northern Puget lowland.

(2) Rapid thinning of the Cordilleran Ice Sheet which began about 13-14 ka years BP allowed marine water to enter the depressed lowland, floating the remaining ice and depositing Kulshan glaciomarine drift between about 12-13 ka years BP.

(3) Isostatic rebound rates exceeded eustatic sea level rise, causing emergence of the lowland, leading to deposition the Deming sand at about 11,5 ka years BP.

(4) Resubmergence of the northern lowland and reintroduction of floating Cordilleran ice deposited Bellingham glacio- marine drift. The postglacial eustatic sea level rise at 11-12 ka years, based on global eustatic sea level curves, was considerably less than the Bellingham resubmergence $(\sim 200 \mathrm{~m})$, especially in view of the fact that any eustatic rise would need to be significantly greater than the isostatic rebound rate of the lowland. Thus tectonic subsidence is required to explain the magnitude of the submergence.

(5) Rapid emergence of the lowland at about 10,5-11,5 ka years permits deposition of Sumas outwash on Bellingham glaciomarine drift. This emergence could be from continuing, rapid isostatic rebound. The general absence of post-Sumas marine terraces in the region suggests that for most of the Holocene, eustatic sea level rise kept pace with isostatic rebound.

\section{FRASER GLACIATION OF THE OKANOGAN LOBE}

At the same time as the Puget and Juan de Fuca lobes were moving into the lowland west of the Cascades, other lobes of the Cordilleran Ice Sheet were also moving southward onto the Columbia Plateau east of the Cascades. The largest of these, the Okanogan lobe, was contiguous across the Cascades with Cordilleran ice west of the mountains at latitudes north of the Skagit River. Although no radiocarbon dates are available from deposits of the Okanogan lobe, it seems to have advanced and retreated approximately contemporaneously with Cordilleran ice west of the Cascades (Easterbrook, 1979).

At its Late Wisconsinan maximum, the Okanogan lobe extended about $50 \mathrm{~km}$ south of the Columbia River, covering deposits of earlier glaciations, so little is known of them. Whereas the Puget and Juan de Fuca lobes advanced to their maximum stand and remained for only a short time, the Okanogan lobe terminus stabilized for a long enough time to build the Withrow moraine, a broad, hummocky moraine $1-2 \mathrm{~km}$ wide and $30-70 \mathrm{~m}$ high across the western portion of the Columbia Plateau (Fig. 21). The large size of the end moraine, relative to the insignificant end moraine of the Puget lobe, suggests that the Okanogan ice terminus remained stable for a longer interval. Well-formed drumlins and low-relief flutes are common behind the end moraine, describing a radial pattern (Fig. 21).

The nature of the advance of the Okanogan lobe is not known because of the lack of exposure of material beneath Vashon till and the lack of radiocarbon dates from any of the drift. However, because the Okanogan lobe was physically connected with the western lobes of the Cordilleran glacier across the northern Cascade Range, the Okanogan advance was very likely coincident with the advance of the well-dated Puget lobe, but direct confirmation remains to be achieved. The Okanogan lobe probably reached its maximum stand about 15 ka years $B P$, but the impressive dimensions of the Withrow moraine suggest that the Okanogan lobe was stable near its terminal position for a longer period than the Puget lobe (Easterbrook, 1976a, 1979).

North of the Withrow moraine numerous eskers, kames, kettles, kame terraces, and related ice-contact sediments suggest that widespread glacier stagnation occurred during deglaciation of the Okanogan lobe. The recessional phase of the Okanogan lobe, named the Mansfield Interstade by Easterbrook (1979) began with retreat of the Okanogan lobe from the Withrow 


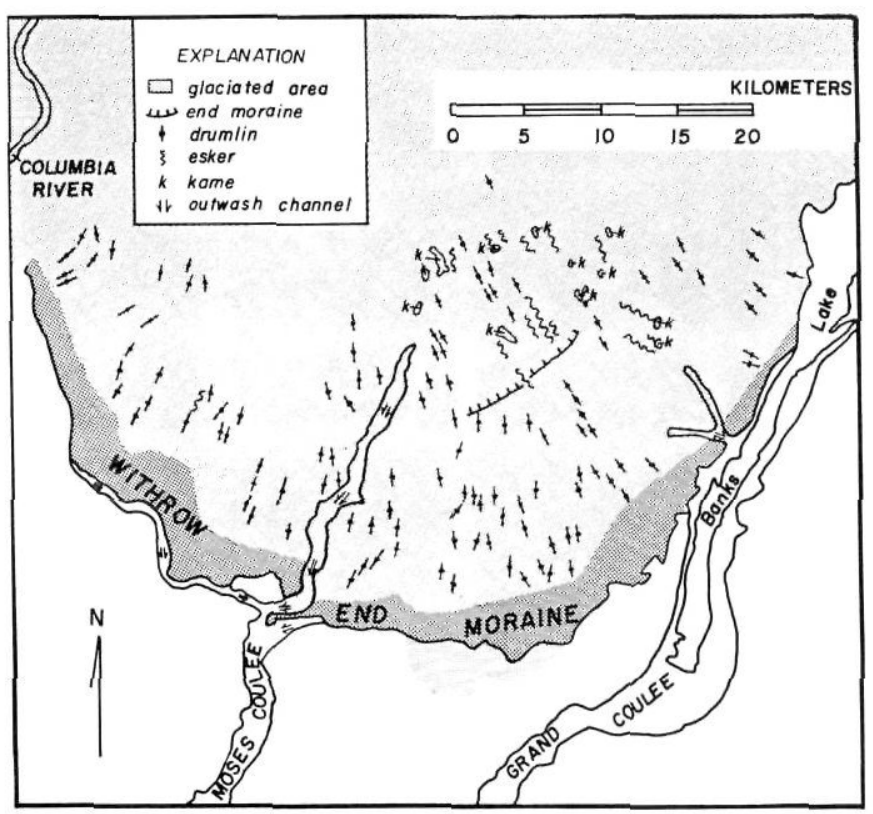

FIGURE 21. Vashon end moraine and ice contact deposits of the Okanogan lobe.

Moraine frontale de Vashon et dépôts de contact glaciaire du lobe d'Okanogan.

moraine, included extensive ice-contact deposition, and ended upon withdrawal of ice from the Columbia Plateau. Low-relief recessional moraines and eskers terminating at ice-marginal fans mark temporary halts in the recession of the glacier terminus.

The same drastic late Pleistocene climatic warming that caused rapid downwasting of the Puget lobe about 13 to $14 \mathrm{ka}$ years ago also affected the Okanogan lobe, but the different depositional environment produced sharply contrasting sediments. The eskers, kames, and other ice stagnation features of the Mansfield Interstade are thought to be comparable in age to the well-dated glaciomarine deposits of the Everson Interstade, i.e., $\sim 11,5$ to 13 ka years (Easterbrook, 1976a).

\section{SUMAS READVANCE}

A brief readvance of Cordilleran ice from British Columbia into northern Washington following the end of glaciomarine deposition occurred during the Sumas stade (Easterbrook, 1963, 1966a, 1966b, 1969, 1971, 1976d; Armstrong, 1977, 1981; Armstrong et al., 1965. Sumas till and ice contact deposits lie directly on outwash near the US-Canadian border, indicating that a period of outwash deposition preceded a subaerial readvance of ice and that the Sumas readvance was not just due to grounding of floating ice (Easterbrook, 1963). Wood from Sumas till in British Columbia has been radiocarbon dated at $11,600 \pm 280$ (GSC-1675), 11,500 \pm 1100 (L-221D), 11,400 \pm 170 (GSC-1695) (Armstrong et al., 1965; Armstrong, 1981) (Fig. 22). Numerous erratics on Sumas Drift are derived from the Fraser Canyon in British Columbia where radiocarbon dates of $11,430 \pm 150$ (1-6057), 11,140 \pm 260 (1-6058), $11,000 \pm 170$ (1-5346) from bogs indicate that the canyon was ice-free by then (Mathews et al., 1972; Mathews and Heusser, 1981; Mathews and Rouse, 1975). The radiocarbon dates from

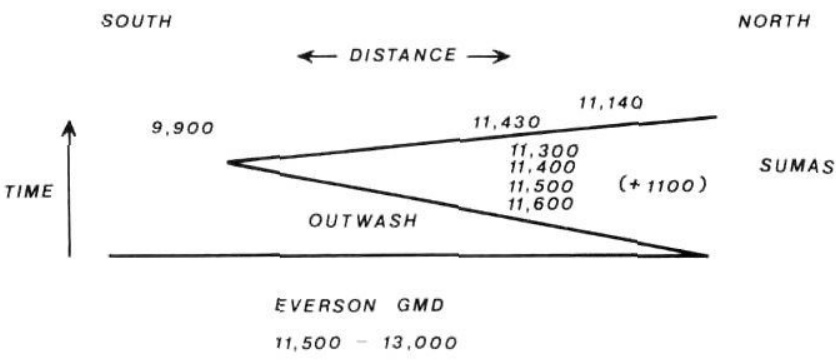

FIGURE 22. Radiocarbon chronology of the Sumas Stade.

Chronologie au radiocarbone du stade de Sumas.

the Fraser Canyon have led to speculation that perhaps the source of Sumas ice was the Coast Mountains, rather than the Fraser Canyon. However, erratics indicate a Fraser Valley source. Clague (1981) points out that the dates allow the possibility of up to $250 \mathrm{~m}$ of ice in the canyon at 11,430 \pm 150 and 150 m of ice at $11,140 \pm 260$ years, and that valleys from alternative source areas were known to be ice free during the climax of the Sumas stade. Sumas ice also filled the Columbia Valley of Washington and the contiguous lower Chilliwack Valley of British Columbia in the Cascade Mountains with up to $250 \mathrm{~m}$ of outwash and ice-contact deposits containing wood radiocarbon dated at 11,300 \pm 100 (GSC-2523) (Armstrong, 1981; Clague, 1980). Radiocarbon dates of 9,920 \pm 760 (I-2280), $9,750 \pm 150$ (WW-6), 9,500 \pm 200 (WW-8), and 9,300 \pm 250 (I-2281) from the bases of peat bogs in abandoned outwash channels indicate that meltwater from Sumas ice had ended by then (Easterbrook, 1963, 1969, 1971).

\section{CONCLUSIONS}

The advance of the Cordilleran Ice Sheet during each of the three youngest glaciations, the Double Bluff, Possession, and Fraser, was typified by the spreading of an apron of outwash in front of the advancing ice which was later overridden. The advance outwash deposits were deeply scoured by the overriding ice, incorporating previously rounded pebbles and cobbles in till which was deposited upon the truncated outwash sediments. Rates of advance, based on limiting radiocarbon dates and extent of the ice, were about $80-110 \mathrm{~m} / \mathrm{yr}$.

At the maximum extent of the Cordilleran Ice Sheet, thicknesses in the Puget Lowland varied from about $1818 \mathrm{~m}$ near the US-Canadian border to about $900 \mathrm{~m}$ in the vicinity of Seattle. The surface slope of the ice, reconstructed from the height of erratics along the adjacent foothills, was about $60 \mathrm{~cm} / \mathrm{km}$.

Retreat of the ice sheet from its southern terminus began by backwasting of the glacier to about the latitude of Seattle. During backwasting, the glacier also thinned considerably, eventually allowing marine water from the Strait of Juan de Fuca to enter the Puget Lowland and float the remaining ice, resulting in widespread deposition of glaciomarine drift, characteristic of all three of the last Cordilleran ice glaciations. Radiocarbon dating of the early phases of backwasting suggest that both the Puget and Juan de Fuca lobes retreated synchronously. The distribution of radiocarbon dates from glaciomarine drift indicate that deposition took place essentially simultaneously in the central Puget Lowland and in British Columbia and 
that deposition could not therefore be from calving of a backwasting ice sheet.

The pattern of isostatic, eustatic, and tectonic events needed to explain stratigraphic and radiocarbon relationships of the Everson glaciomarine drift in the northern Puget Lowland is:

(1) Glacial loading during the Vashon maximum depressed the northern Puget lowland.

(2) Rapid thinning of the Cordilleran Ice Sheet, which began about 13-14 ka years BP., allowed marine water to enter the depressed lowland, floating the remaining ice and depositing Kulshan glaciomarine drift between about $12-13$ ka years BP.

(3) Isostatic rebound rates exceeded eustatic sea level rise, causing emergence of the lowland, leading to deposition the Deming sand at $\sim 11.5$ ka years BP.

(4) Resubmergence of the northern lowland and reintroduction of floating Cordilleran ice deposited Bellingham glaciomarine drift. Global eustatic sea level curves suggest that the postglacial eustatic sea level rise at 11-12 ka years was not great enough to explain the order of magnitude of the Bellingham resubmergence $(\sim 200 \mathrm{~m})$, especially in view of the fact that it would need to be significantly greater than the isostatic rebound rate of the lowland. Thus, tectonic subsidence is required to explain the magnitude of the submergence.

(5) Rapid emergence of the lowland at about 10.5-11.5 ka years permitted deposition of Sumas outwash on Bellingham glaciomarine drift. This emergence could be from continuing, rapid, isostatic rebound. The general absence of post-Sumas marine terraces in the region suggests that eustatic sea level rise kept pace with isostatic rebound for most of the Holocene.

The Sumas readvance was a minor oscillation in the overall retreat of the Cordilleran Ice Sheet, very similar to that observed in Europe, South America, and New Zealand.

\section{REFERENCES}

Alley, N. F., 1979. Middle Wisconsin stratigraphy and climatic reconstruction, southern Vancouver Island, British Columbia. Quaternary Research, 2: 213-237.

Anderson, F. E., 1968. Seaward terminus of the Vashon continental glacier in the Strait of Juan de Fuca. Marine Geology, 6: 419-438.

Armstrong, J. E., 1977. Quaternary stratigraphy of the Fraser Lowland. Geological Society of America Annual Meeting, Guidebook for Field Trip No. 6: 204-226.

- 1981. Post-Vashon Wisconsin glaciation, Fraser Lowland, British Columbia. Geological Survey of Canada Bulletin, 322, 34 p.

Armstrong, J. E. and Brown, W. L., 1954. Late Wisconsin marine drift and associated sediments of the lower Fraser Valley, British Columbia, Canada. Geological Society of America Bulletin, 65: 349-364.

Armstrong, J. E. and Clague, J. J., 1977. Two major Wisconsin lithostratigraphic units in southwest British Columbia. Canadian Journal of Earth Sciences, 14: $1471-1480$.

Armstrong, J. E. and Hicock, S. R., 1976. Quaternary multiple valley development of lower Coquitlam Valley, Coquitlam, British Columbia. Geological Survey of Canada Paper 76-1B: 197-200.

Armstrong, J. E., Clague, J. J. and Hebda, R. J., 1985. Late Quaternary geology of the Fraser Lowland, southwestern British Columbia. Guidebook for Field
Trip 15, Geological Society of America, Cordilleran Section Meeting, Vancouver, $\mathrm{BC}, 25 \mathrm{p}$.

Armstrong, J. E., Crandell, D. R., Easterbrook, D. J. and Noble, J. B., 1965. Late Pleistocene stratigraphy and chronology in southwestern British Columbia and northwestern Washington. Geological Society of America Bulletin, 76: 321-330.

Blunt, D. J., Easterbrook, D. J. and Rutter, N.W., 1987. Chronology of Pleistocene sediments in the Puget Lowland, Washington. Washington Division of Geology and Earth Resources Bulletin, 77: 321-353.

Booth, D. B., 1987. Timing and processes of deglaciation along the southern margin of the Cordilleran ice sheet, p. 79-90. In W. F. Ruddiman and H. E. Wright, Jr., eds., North America and adjacent oceans during the last deglaciation. Geological Society of America, The Geology of North America, vol. K-3.

Bretz, J. H., 1913. Glaciation of the Puget Sound region. Washington Division of Mines and Geology Bulletin, 8, 244 p.

-1920. The Juan de Fuca lobe of the Cordilleran ice sheet. Journal of Geology, 28: 333-339.

Carson, R. J., 1970. Quaternary geology of the south-central Olympic Peninsula, Washington. Ph.D. Thesis, University of Washington, Seattle, 67 p.

Cary, A. S. and Carlston, C. W., 1937. Notes on Vashon stage glaciation of the South Fork of the Skykomish River valley, Washington. Northwest Science, 11: 61-62.

Clague, J. J., 1976. Quadra Sand and its relation to the late Wisconsin glaciation of southwest British Columbia. Canadian Journal of Earth Sciences, 13: 803-815.

1977. Quadra Sand: A study of the late Pleistocene geology and geomorphic history of coastal southwest British Columbia. Geological Survey of Canada Paper 77-17, 24 p.

1978. Mid-Wisconsinan climates of the Pacific Northwest. Geological Survey of Canada Paper 78-IB: 95-100.

- 1980. Late Quaternary geology and geochronology of British Columbia, Part 1: Radiocarbon dates. Geological Survey of Canada Paper 80-13, 28 p.

- 1981. Late Quaternary geology and geochronology of British Columbia, Part 2: Summary and discussion of radiocarbon-dated Quaternary history. Geological Survey of Canada Paper 80-35, 41 p.

Clague, J. J. and Luternauer, J. L., 1982. Late Quaternary sedimentary environments, southwestern British Columbia. International Association of Sedimentology, 11th International Congress, Field Excursion Guide Book 30A, $167 \mathrm{p}$.

- 1983. Late Quaternary geology of southwestern British Columbia. Geological Association of Canada Annual Meeting, Field Trip no. 6, Field Trip Guidebook, vol. 1, 112 p.

Clague, J. J., Armstrong, J. E. and Mathews, W. H., 1980. Advance of the late Wisconsin Cordilleran ice sheet in southern British Columbia since 22,000 yr. Quaternary Research, 13: 322-326.

Crandall, R., 1979. Diatoms and magnetic anisotropy as means of distinguishing glacial till from glaciomarine drift. M.Sc. Thesis, Western Washington University, Bellingham, $62 \mathrm{p}$.

Crandell, D. R., 1963. Surficial geology and geomorphology of the Lake Tapps Quadrangle, Washington. U.S. Geological Survey Professional Paper 388-A, 84 p.

Crandell, D. R., Mullineaux, D. R. and Waldron, H. H., 1958. Pleistocene sequence in the southeastern part of the Puget Sound Lowland, Washington. American Journal of Science, 256: 384-398.

Curran, T. A., 1965. Surficial geology of the Issaquah area, Washington. M.Sc. thesis, University of Washington, Seattle.

Deeter, J. D., 1979. Quaternary geology and stratigraphy of Kitsap County, Washington. M.Sc. thesis, Western Washington University, Bellingham, $175 \mathrm{p}$.

Domack, E. W., 1983. Facies of late Pleistocene glacial sediments on Whidbey Island, Washington, p. 535-570. In Glacial-marine Sedimentation. Plenum Press, New York. 
Dorn, T. F., Fairhall, A. W., Schell, W. R. and Takashima, Y., 1962. Radiocarbon dating at the University of Washington I. Radiocarbon, 4: 1-12.

Easterbrook, D. J., 1963. Late Pleistocene glacial events and relative sea-level changes in the northern Puget Lowland, Washington. Geological Society of America Bulletin, 74: 1465-1483.

_- 1966a. Radiocarbon chronology of late Pleistocene deposits in northwest Washington. Science, 152: 764-767.

_ 1966b. Glaciomarine environments and the Fraser Glaciation in northwest Washington. Guidebook for First Pacific Coast Friends of the Pleistocene Field Conference, $52 \mathrm{p}$.

1968. Pleistocene stratigraphy of Island County, Washington. Washington Division of Water Resources Bulletin, 25: 1-34.

- 1969. Pleistocene chronology of the Puget Lowland and San Juan Islands, Washington. Geological Society of America Bulletin, 80: 2273-2286.

1970. Glacial events in the Puget Lowland between 14,000 and 10,000 years ago. American Quaternary Association Abstracts, p. 39.

- 1971. Geology and geomorphology of western Whatcom County, Washington. Western Washington University Press, Bellingham, $68 \mathrm{p}$.

- 1974. Comparison of late Pleistocene glacial fluctuations, p. 96-109. In V. Sibrava, ed., Quaternary Glaciations in the Northern Hemisphere. International Geological Correlation Project 73/1/24, Report no. 1.

- 1976a. Quaternary geology of the Pacific Northwest, p. 441-462. In W. C. Mahaney, ed., Quaternary Stratigraphy of North America. Dowden, Hutchinson, and Ross, Stroudsburg.

- 1976b. Middle and early Wisconsin chronology in the Pacific Northwest, p. 90-98. In D. J. Easterbrook and V. Sibrava, eds., Quaternary Glaciations in the Northern Hemisphere. International Geological Correlation Program, Project 73/1/24, Report no. 3.

_ 1976c. Stratigraphy and palynology of late Quaternary sediments in the Puget Lowland, Washington. Geological Society of America Bulletin, 87: 155-156.

— 1976d. Geologic map of western Whatcom County, Washington. U.S. Geological Survey Miscellaneous Investigations, Map I-854B.

1979. The last glaciation of northwest Washington, p. 177-189. In J. M. Armentrout, M. R. Cole and H. Terbest, eds., Cenozoic Paleogeography of the Western United States. Pacific Coast Paleogeography Symposium 3, Los Angeles, Pacific Coast Section, Society of Economic Paleontologists and Mineralogists.

1982. Characteristic features of glacial sediments. American Association of Petroleum Geologists, Memoir 31: 1-10.

-1986. Stratigraphy and chronology of Quaternary deposits of the Puget Lowland and Olympic Mountains of Washington and the Cascade Mountains of Washington and Oregon, p. 145-169. In V. Sibrava, D. Q. Bowen and G. M. Richmond, ed., Quaternary Glaciations in the Northern Hemisphere. Quaternary Science Reviews.

1988. Dating Quaternary Sediments. Geological Society of America Special Paper 227, $165 p$.

Easterbrook, D. J. and Rutter, N. A., 1981. Amino acid ages of Pleistocene glacial and interglacial sediments in western Washington. Geological Society of America Abstracts with Programs, 13: 444.

- 1982. Amino acid analysis of wood and shells in development of chronology and correlation of Pleistocene sediments in the Puget Lowland, Washington. Geological Society of America Abstracts with Programs, 14: 480 .

Easterbrook, D. J., Blunt, D. J. and Rutter, N. A., 1982. Pleistocene glacial and interglacial chronology in western Washington. Geological Society of America Abstracts with Program, 14: 161.

Easterbrook, D. J., Crandell, D. R. and Leopold, E. B., 1967. Pre-Olympia Pleistocene stratigraphy and chronology in the central Puget Lowland, Washington. Geological Society of America Bulletin, 78: 13-20.

Easterbrook, D. J., Briggs, N. D., Westgate, J. A. and Gorton, M. P., 1981. Age of the Salmon Springs Glaciation in Washington. Geology, 9: 87-93.
Fulton, R. J., Armstrong, J. E. and Fyles, J. G., 1976. Stratigraphy and palynology of late Quaternary sediments in the Puget Lowland, Washington: discussion. Geological Society of America Bulletin, 87: 153-155.

Hansen, B. S. and Easterbrook, D. J., 1974. Stratigraphy and palynology of late Quaternary sediments in the Puget Lowland, Washington. Geological Society of America Bulletin, 85: 587-602.

Hansen, H. P. and Mackin, J. H., 1949. A pre-Wisconsin forest succession in the Puget Lowland, Washington. American Journal of Science, 47: 833-855.

Heusser, C. J., 1973a. Environmental sequence following the Fraser advance of the Juan de Fuca lobe, Washington. Quaternary Research, 3: 284-306.

1973b. Age and environment of allochthonous peat clasts from the Bogachiel River Valley, Washington. Geological Society of America Bulletin, 84: 797-804.

1977. Quaternary palynology of the Pacific slope of Washington. Quaternary Research, 8: 282-306.

1982. Quaternary vegetation and environmental record of the western Olympic Peninsula. American Quaternary Association, 7th Biennial Conference, Seattle, Guide for Day 2 of Field Trip G, 23 p.

Hicock, S. R., 1976. Quaternary geology: Coquitlam-Port Moody area, British Columbia. M.Sc. thesis, University British Columbia, Vancouver, 114 p.

1980. Pre-Fraser Pleistocene stratigraphy, geochronology, and paleoecology of the Georgia Depression, British Columbia. Ph.D. thesis, University of Western Ontario, London, $230 \mathrm{p}$.

Hicock, S. R. and Armstrong, J. E., 1981. Coquitlam Drift: a pre-Vashon Fraser glacial formation in the Fraser Lowland, British Columbia. Canadian Journal of Earth Sciences, 18: 1443-1451.

1985. Vashon Drift: definition of the formation in the Georgia Depression, southwest British Columbia. Canadian Journal of Earth Sciences, 22: 748-757.

Hicock, S. R., Hebda, R. J. and Armstrong, J. E., 1982. Lag of Fraser glacial maximum in the Pacific Northwest: pollen and macrofossil evidence from western Fraser Lowland, British Columbia. Canadian Journal of Earth Sciences, 19: 2288-2296.

Hicock, S. R., Hobson, K. and Armstrong, J. E., 1982. Late Pleistocene proboscideans and early Fraser glacial sedimentation in eastern Fraser Lowland, British Columbia. Canadian Journal of Earth Sciences, 19: 899-906.

Keddie, G. R., 1979. The Late Ice Age of southern Vancouver Island. Midden, 11: 16-22.

Lea, P. D., 1983. Glacial history of the southern margin of the Puget Lowland, Washington. Geological Society of America Abstracts with Programs, 15: 430.

1984. Pleistocene glaciation at the southern margin of the Puget Lobe, western Washington. M.Sc. thesis, University of Washington, Seattle, $96 \mathrm{p}$.

Leopold, L. B., Nickmann, R., Hedges, J. I. and Ertel, J. R., 1982. Pollen and lignin records of late Quaternary vegetation, Lake Washington. Science, 218: 1305-1307.

Mackin, J. H., 1941. Glacial geology of the Snoqualmie-Cedar area, Washington. Journal of Geology, 49: 449-481.

Mathews, R. W. and Heusser, L. E., 1981. A 12,000 year palynological record of temperature and precipitation trends in southwestern British Columbia. Canadian Journal of Botany, 59: 707-710.

Mathews, R. W. and Rouse, G. E., 1975. Palynology and paleo-ecology of postglacial sediments from the lower Fraser canyon of British Columbia. Canadian Journal of Earth Sciences, 12: 745-756.

Mathews, R. W., Borden, C. E. and Rouse, G. E., 1972. New radiocarbon dates from the Yale area of the lower Fraser River canyon, British Columbia. Canadian Journal of Earth Sciences, 9: 1055-1057.

Mullineaux, D. R., Waldron, H. H. and Rubin, M., 1965. Stratigraphy and chronology of late interglacial and early Vashon time in the Seattle area, Washington. U.S. Geological Survey Bulletin, 1194-O: 1-10.

Newcomb, R. C., 1952. Groundwater resources of Snohomish County, Washington. U.S. Geological Survey Water Supply Paper, 1135: 1-133. 
Noble, J. B. and Wallace, E. F., 1966. Geology and groundwater resources of Thurston County, Washington. Washington State Division of Water Resources, Water Supply Bulletin, 10: 1-61.

Pessl, F. et al., 1981. Sedimentary facies and depositional environments of late Wisconsin glacial-marine deposits in the central Puget Lowland, Washington. American Association of Petroleum Geologists Abstracts, San Francisco.

Petersen, K. L., Mehringer, P. J. and Gustafson, C. E., 1983. Late-glacial vegetation and climate at the Manis Mastodon site, Olympic Peninsula, Washington. Quaternary Research, 20: 215-231.

Richmond, G. M., 1986. Tentative Correlation of Deposits of the Cordilleran IceSheet in the Northern Rocky Mountains, p. 129-144. in V. Sibrava, D. Q. Bowen and G. M. Richmond, eds., Quaternary Glaciations in the Northern Hemisphere. Quaternary Science Reviews, 5.

Rigg, G. B. and Gould, H. R., 1957. Age of Glacier Peakeruption and chronology of postglacial peat deposits in Washington and surrounding areas. American Journal of Science, 255: 341-363.
Siegfried, R. T., 1978. Stratigraphy and chronology of raised marine terraces, Bay View Ridge, Skagit County, Washington. M.Sc. thesis, Western Washington University, Bellingham, $52 \mathrm{p}$.

Thorson, R. M., 1980. Ice sheet glaciation of the Puget Lowland, Washington, during the Vashon Stade. Quaternary Research, 13: 303-321.

- 1981. Isostatic effects of the last glaciation in the Puget Lowland Washington. U.S. Geological Survey Open-File Report 81-370, 100 p.

Waitt, R. B. and Thorson, R. M., 1983. The Cordilleran ice sheet in Washington, Idaho, and Montana, p. 53-70. In S. C. Porter, ed., Late Quaternary Environments of the U.S., Vol. 1, The Late Pleistocene. University of Minnesota Press, Minneapolis.

Westgate, J. A., Easterbrook, D. J., Naeser, N. D. and Carson, R. J., 1987. Lake Tapps Tephra: An early Pleistocene stratigraphic marker in the Puget Lowland, Washington. Quaternary Research, 28: 340-355.

Willis, B., 1898. Drift phenomena of Puget Sound. Geological Society of America Bulletin, 9: 111-162.

Yount, J. C., Marcus, K. L. and Mozley, P. S., 1980. Radiocarbon-dated localities from the Puget Lowland, Washington. U.S. Geological Survey Open File Report 80-780, 51 p. 